\title{
Ordination of Selected Traditional Japanese Gardens, Traditional Chinese Gardens, and Modern Chinese Gardens
}

\author{
Dexin Chen \\ School of Planning, Design, and Construction, Michigan State University \\ 552 W. Circle Drive, East Lansing, MI 48824, United States \\ E-mail: chendexi@msu.edu \\ Jon Bryan Burley (Corresponding author) \\ School of Planning, Design, and Construction, Michigan State University \\ 552 W. Circle Drive, East Lansing, MI 48824, United States \\ Tel: 1-989-862-4284Ｅ-mail: burleyj@msu.edu
}

Trisha Machemer

School of Planning, Design, and Construction, Michigan State University

552 W. Circle Drive, East Lansing, MI 48824, United States

E-mail: machemer@msu.edu

Robert Schutzki

Department of Horticulture, Michigan State University

1066 Bogue Street, East Lansing, MI 48824, United States

E-mail: schutzki@msu.edu

Received: January 25, 2021 Accepted: February 10, $2021 \quad$ Published: February 20, 2021

doi:10.5296/ijch.v8i1.18250 URL: https://doi.org/10.5296/ijch.v8i1.18250 


\section{Abstract}

Designers and academics are interested in the characteristics, differences, and similarities between built environments such as garden types. This investigation aims to examine the ordination of traditional Japanese gardens in Kyoto, the classical Chinese gardens in Suzhou and the modern Chinese gardens in Xiamen. A hundred and thirty-four variables were selected for the ordination. According to a Principal Component Analysis (PCA) ordination, the first three principal components covered 70.77 percent of the sample variance: the first principal component (traditional Asian values to non-Asian dimension) and second principal component (a complexity to simplicity dimension) divides the gardens into three identifiable groups; the first and the third principal component (a hardscape to softscape dimension) indicates the similarities of traditional Japanese gardens and classical Chinese gardens; the second and third principal component implies the similarities of traditional Japanese gardens and modern Chinese gardens.

Keywords: landscape architecture, environmental design, historic gardens, contemporary gardens, garden design

\section{Introduction}

\subsection{Intent}

Understanding the differences between Chinese and Japanese gardens have been only modestly explored. For the most part, there is a large body of literature about Chinese gardens and a growing body of literature on Japanese gardens. "Having traveled to Japan 22 times, spoken at Nodai University in Tokyo twice visiting many of the gardens and temples in Kyoto and traveled to China 20 times speaking at 13 universities and visiting the landscapes from Lijiang in Yunnan Province to Dalian in Liaoning Province, I was intrigued by the relationships between the two, yet how little my academic colleagues from both countries knew of each other's traditions in design. The same was true of my colleagues in South Korea, which I have visited 3 times and have spoken at Seoul National University. They knew much of their culture and very little of their neighbors, but often knew much more about design in the United States or Europe than their neighbors. Colleagues from each of these nations suggested that there were strong pressures to investigate areas within their own nation and to continue a long narrative derived from their nation. Many times, I was told by these Asian academics that I seemed to have a much better understanding of the relationships, similarities, and differences in garden design between the nations than they did. I am an American academic and had opportunities to see these places with fresh eyes, and free of the cultural/social limitations that prevented them from making observations and comparisons." stated Dr. Burley. Exploring these similarities and differences would take many investigations and published articles by numerous experts. This study is one of the few that have begun to explore the relationships amongst Asian designs across nations.

\subsection{Literature}

The evaluation and comparison of various garden types has traditionally been described and compared through the heuristic evaluation and opinions of built environment experts and 
historians, as illustrated by Chen and Burley (2018), Burley and Machemer (2016), Burley and Kopinski (2014), Liu et al. (2014), Kopinski and Burley (2013), Monsma et al. (2011), Burley and Loures (2010), Casault and Burley (2010), Burley (1992), Netwon (1974), and Tobey (1973). Much of the literature is in the form of expert-based opinion to explore differences in various gardens such as between gardens of the world (Boults and Sullivan 2010), Chinese and Japanese gardens (Chen 2008), visual impressions of traditional Chinese gardens and modern gardens (Yang \& Volkman, 2010) or Chinese gardens and the West (Wuzhong 2005). Recently, investigators have been employing science-based methods to understand the composition of both modern and historic gardens and other exterior environments. For example, Zhao et al. (2003) employed a respondent-based survey to compare visual images of gardens in in China and Japan; while Yue et al. (2012) applied fractal geometry to reliably replicate the characteristics of a garden in Suzhou, China. Peng (2016) studied the differences in the use of stones between Chinese and Japanese temple gardens, where the Chinese employ sculptural limestone and the Japanese primarily employ angular, rough-hewn and smooth, river-washed volcanic and related metamorphic rocks. Haoxuan $\mathrm{Xu}$ et al. (2017) employed principal component analysis (PCA) to compare selected Chinese burial sites with selected American cemeteries discovering similarities and differences employing qualitative data. This multivariate approach has been widely utilized in surface mine reclamation studies, plant ecology studies to compare stands of vegetation, and in geography, as illustrated by Burley et al (2020), Bai et al. (2016), Qi et al. (2012), Burley et al. (2001), Burley at al. (1989), and Curtis (1959). Wen and Burley (2020) applied this approach to study a compare the characteristics of traditional Chinese village in Hunan with non-traditional villages. Yiwen Xu et al. (2016) also applied this general methodology to compare three traditional Chinese gardens (which were believed by experts to be extremely similar, as social pressures to deviate to far from an expected norm would results in trouble) with five contemporary gardens in China (which were believed to be more divergent in expression). At the time there was little empirical evidence that this was true, only expert opinion. The investigation quantitatively confirmed that indeed, the traditional Chinese gardens examined were quite similar despite each having a different conceptual metaphor to generate the design, concentrated around a multidimensional volume/space, a claim that has been widely made in the opinion of scholars studying such gardens (Burley \& Machemer, 2016). In contrast modern gardens are much more broadly different with each design being unique and often quite divergent in design components, where each garden attempts to create a special experience (Burley \& Machemer, 2016). The study of these built environments has suggested that such investigations are entering an age where projects are compared and contrasted employing a variety of characteristics and metrics in a quantitative manner, exemplified by Feng et al. (2018), Lin et al. (2017), Wang et al. (2015), and Burley and Yilmaz (2014).

There was interest in applying this general methodology to compare and contrast selected traditional Japanese gardens from Kyoto. Knowledge concerning traditional Japanese gardens has been growing over the last fifty years, as illustrated by Bullen (2016), Fowler (2015), Suzuki (2015), Goto et al. (2014), Makowska (2014), Boults and Sullivan (2010), Desranleau and Jacobs (2009), Van Tonder et al. (2002), Trieb and Herman (2003), and Jellicoe and Jellicoe (1975). This is a dramatic change from the mid $20^{\text {th }}$ Century where little was known or 
described in landscape architecture texts concerning Asian built environments, as illustrated Newton (1974), Tobey (1973), and Mangin (1888), not being broadly described and known in the West as designers might wish to understand such environments until publications such as Pregill and Volkman (1999) entered the literature. For the most part, the works of widely travelled Susan Jellicoe and Sir Geoffrey Jellicoe (1975), offered insight to the lesser discussed cultural and designed sites in Japanese, China, Indonesia, Cambodia, Pre-Columbian, and the Indian subcontinent. It should be noted that much earlier Gothein (1928) did acknowledge Asian garden designs, but these texts contained limited insight and understanding concerning these environments and are more of an exposé, illustrating Western values and perception of Asian landscapes with very little understanding of Asian values and perceptions. Siciliano (2005) illustrates the preoccupation with designs in the West. Keswick (1978) began introducing Chinese gardens in a comprehensive manner with a "follow-up" by Valders (2002). Although Sir William Chambers (1772) presented an enthusiastic philosophical treatise promoting Chinese garden design. Cheng's (1631) writings about normative theories to create a Chinese garden is an early insightful text into Chinese thinking with indirect advice. More recent publications concerning Chinese gardens are presented by Jie (2013), Chongzhou (2008), and Qingxi (2003). Within the Chinese journal literature is an extensive body of articles describing repeatedly similar principles concerning the design of the Chinese garden, as though each scholar on the topic often repeats what is widely known, almost like a rite to be welcomed into the academy of garden scholars. Yet there is much that could be written about design in China that goes often unnoticed without "fresh-eyes" from other guests to China, as illustrated by Darkovskaya et al. (2010) and Wang et al. (2010). In contrast, possibly the oldest existing/surviving book concerning garden design is from Japan, the Sakuteiki (作庭記Records of Garden Making) formerly known as Senzai Hissho (Secret Selection on Gardens) describing the creation of ocean, mountain torrents, broad river, wetland, and reed styled gardens, plus other types of ecologically oriented environments (Takei \& Keane 2008). It is interesting how much of the advice in the book is about superstitions, avoiding evil, premature death, and troubles. Recent insightful publications in English concerning Japanese garden design include Kawaguchi (2016), Young and Young (2005), and Kuitert (2002); although, in the Japanese language there are many excellent scholarly texts. Few scholars have addressed the conceptual design statement behind creation of these gardens in a manner similar to Loures and Burley (2009). There is still much that can be revealed about these gardens.

Over the past few decades, scholars have begun to make comparisons between Chinese and Japanese designs. Chen (1991) employed professional opinion and accepted design principles to study the aesthetics between Chinese residential gardens and Japanese dry landscape gardens. In a study by Zhao et al. (2003), respondents were sampled for their impressions of images from Chines and Japanese gardens. The Japanese respondents considered Chinese gardens as dynamic and a mixture of features; while, they considered the Japanese gardens as purity and stillness. In contrast the Chinese respondents considered the Chinese gardens as artificial and complex. The Chinese respondents considered the Japanese gardens as nature and simplicity.

Japanese gardens have Chinese influences dating from the Tang Dynasty but evolved to have a truly distinctive Japanese character (Chen \& Burley, 2018; Burley \& Machemer, 2016; Peng, 
2016; Boults \& Sullivan, 2010; Trieb \& Herman, 2003; Pregill \& Volkman, 1999; Kuck 1968). Although traditional Japanese gardens and classical Chinese gardens are often related to each other because of the characteristics they have in common, few scholars have used a scientific method (empirical data) to illustrate the similarities and differences between them. In this research, the team applied a statistical method (PCA) to study a group of traditional Japanese gardens, classical Chinese gardens, and modern Chinese gardens to help broaden an understanding of Asian garden designs.

\section{Study Area}

\subsection{Study Area}

The study area included selected gardens in Kyoto. Trieb and Herman (2003) provided an insightful interpretation concerning the origin and current condition for many of these gardens. Traditional classification of Japanese gardens, styles, and periods have been well published Trieb and Herman (2003). For the novice, it might be helpful to consider three basic periods. First there was a time when Japanese site design was most strongly influenced by animism and Shinto beliefs. The second period starts by the time of the Tang Dynasty in China, where Japanese site design is heavily influenced by Chinese ideas, but eventually evolving towards the simplicity of the Zen garden. The shift can be explained by the differences between the bountiful resources in China and the less bountiful islands of Japan. Japan could not compete with the richness of China. A lowly Chinese government official or businessman may have commanded more resources than even a Japanese emperor. The natural migration to expressing more with less can be understood within that context (Burley \& Machemer, 2016). The third phase is the Western-fusion phase where the sensibilities of Japanese design are blended with Western ideas. An example in architecture would be the main train station in Tyoko. In garden design, an example might be the Kiyosumi Gardens in Tokyo where mowed grass (a Western approach) is used in sunlight to give a effect similar to moss in the shade (Tokyo Metropolitan Park Association, undated). However, the use of turf grass (Zoysia japonica Steud.) in small areas can be found in Japanese gardens dating 1,000 years ago (Takei \& Keane 2008)

The Japanese gardens of Kyoto in this study originated in the second era, the time of Chinese influence, as the Japanese evolved their own special garden expressions. Japanese garden historians have carefully divided these Chinese influenced garden types into different periods such as the Nara, Heian, Kamakura, Muromachi, and Edo; yet to the novice, there may be very little that distinguishes a distinct change in style (Chen \& Burley, 2018), but rather a continuation of exploring Chinese contributions. In many respects the changes are often more political and social and less spatial. To illustrate the point, Asians often have difficulty differentiating Romanesque, Italian Renaissance, and Baroque styles, something that Western architects and designers readily distinguish (Burley \& Machemer, 2016). Cultural influences can often determine what one sees and how the artifacts are interpreted (Binford \& Binford 1968). While in the mind of the Japanese scholar the issue is settled, those from outside may be reassessing the classification system. Such debates about classification systems are readily evident in disciplines such as in anthropology (Coe, 1987) and the debate has entered the classifications of Japanese gardens. 
Ten Japanese gardens sites in Kyoto were investigated for this study. Dougill (2017) and Clancy (2015) provide colorful introductions to many of the gardens in the area. Each of the gardens were accessible for the tourist and may not represent the highly detailed introspective notions that scholars of Japanese gardens may have for the little-known gardens and sites investigated and published by these scholars. In fact, the Japanese scholar may not even classify some of the sites studied as gardens. For this study, the broad Western interpretation of what constitutes a garden is employed, where a garden can be primarily a softscape open space, containing plants, water, rocks, soil, wildlife, and small structures found in parks, religious sites, estates, residences, commercial sites and even within lightly tended natural areas or hardscape plazas.

To understand the gardens, it is helpful to review an article by Chen and Burley (2018). Many of the gardens in Kyoto are associated with Buddhist temples. For the most part, such temples and influence were forbidden to be near civic and administrative centers of government and thus were structured outside the city. Many of the temples are affiliated with nearby Shinto Shines (sacred places) - no shrine, then no temple and thus no garden. It has been stated, "no rock, no garden" (Peng 2016); but during these traditional times in Japan, it might be helpful to consider the importance of siting a temple based upon sacredness as an often more defining characteristic for the eventual creation of a garden. Being mandated to be on the outskirts of the city did offer opportunities for the gardens to have stronger feng shui (wind and water) energy derived from the adjacent mountains/hills to the west, north, and east. This is the setting for many of these gardens. Thus, the energy derived from the hills (the dragon) may be important in order to have a temple/garden site for meditation. It appears that at times Western examination of Japanese gardens have focused upon the objects of the garden (stones, lanterns, washing basins, Japanese maples (Acer palmatum Thunb. 1784 not Raf. 1836, Acer japonicum Thunb. 1784, and Acer shirasawanum Koidz. 1911), and raked gravel than the actual metaphors employed in the garden, barrowed scenery, the overall context for implementing a garden (Chen \& Burley, 2018). The same can be said for the Chinese garden, where Westerners who cannot read the poem above the gateway ignore the storyline concerning the concept and idea that Chinese garden is embellishing (Liu, Burley \& Partin, 2014),

\subsubsection{Shisen-do}

In the Edo period, Ishikawa Jozan escaped to Kyoto because of opposing the military rule and built Shisen-do in 1636. During the forty years living in Shisen-do, Ishikawa studied tea, arts, philosophy and garden design (Treib \& Herman, 2003). At first Shisen-do was designed to be a private villa, today it has become a Zen temple (Figure 1), (Mehta, Tada \& Murata, 2008).

Portraits of thirty-six Chinese and Japanese poets were shown on the wall of the main building. The design of Shisen-do was called "literary man's style". The main viewing veranda, the raked sand area, the nicely trimmed bushes and the natural vegetation in the background composite the major impression of Shisen-do (Treib \& Herman, 2003). Shisen-do is also famous for its unique water device, Shishiodoshi, which is made of bamboo and make sounds when motivated by the water stream to hit the rock. The function of this device is to scare deer and other animals away, while it provides a sound of silence in the garden (Mehta, Tada, \& Murata, 2008). 


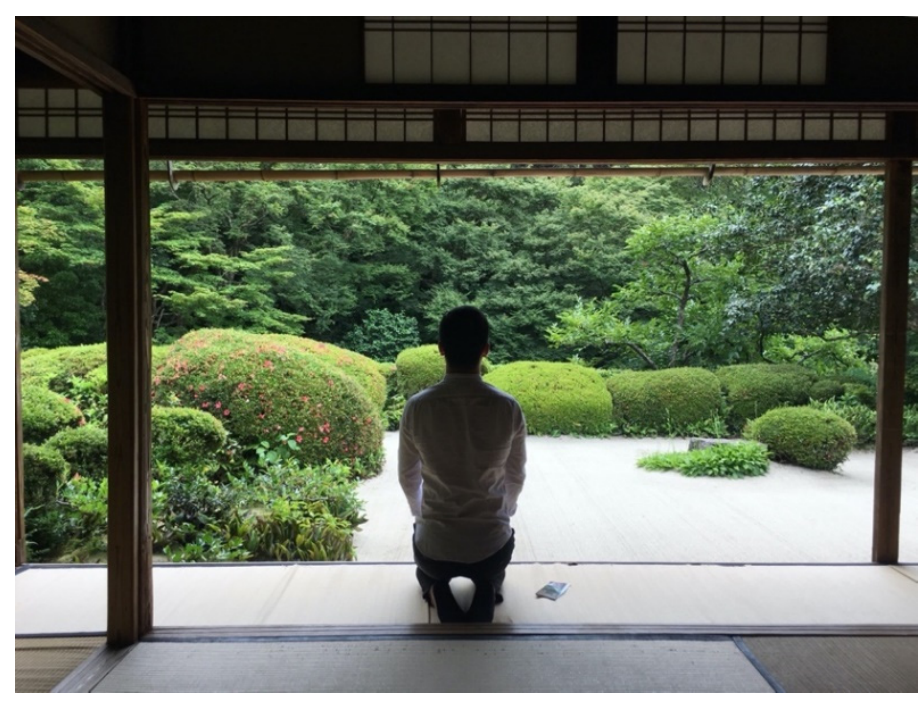

Figure 1. Meditation in Shisen-do While Viewing the Dry Landscape

Note: (Copyright C2017 Dexin Chen all rights reserved used by permission).

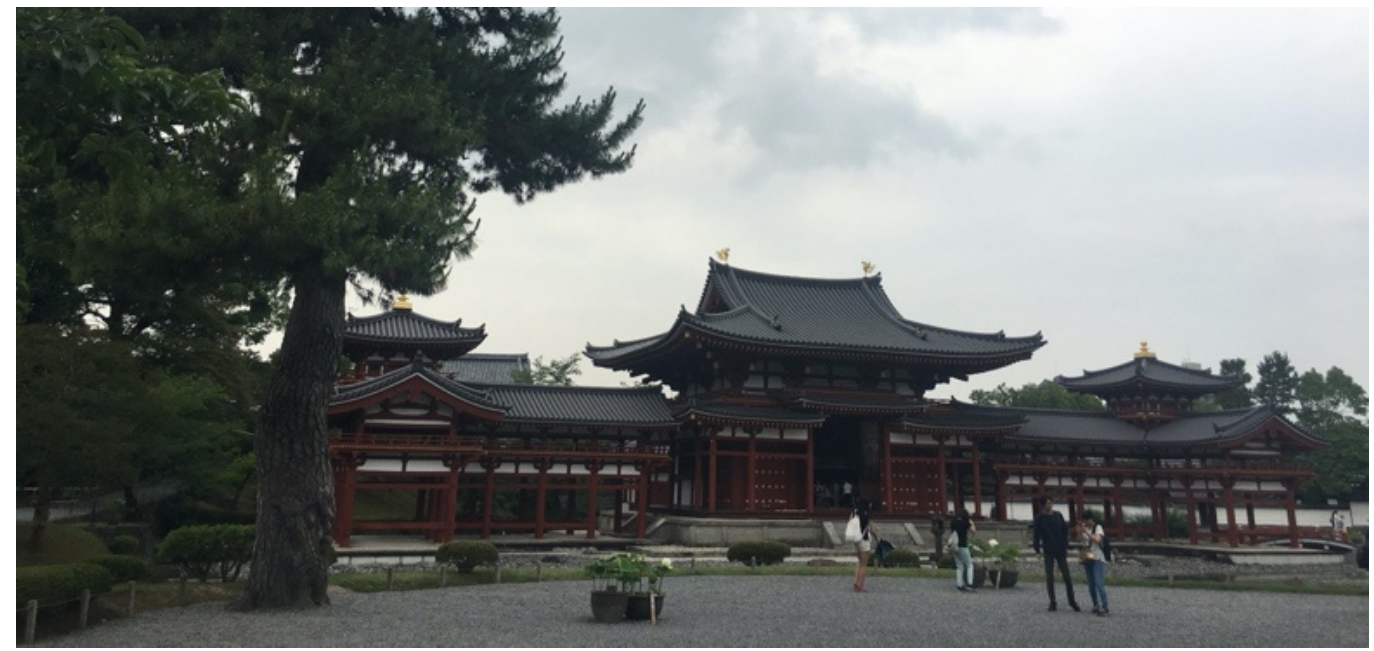

Figure 2. The Phoenix Hall of Byodo-in Temple

Note: (Copyright C2017 Dexin Chen, all rights reserved used by permission).

\subsubsection{Byodo-in}

In Heian period, Fujiwara Yorimichi, a member of the imperial court, built a palace in the former villa of Fujiwara Michinaga, which was turned into a Buddhism temple in 1052 (Figure 2). Only the Phoenix Hall survived among the building complex, it best represented the architecture style of Heian period. Functionally, the Phoenix Hall is used as a chapel of Amida Buddha. The main hall and the arcades on both sides were believed to be the metaphor of a phoenix to land or to take off. The entire setting of the garden was based on the imagination of Amida's western palace (Treib \& Herman, 2003). 


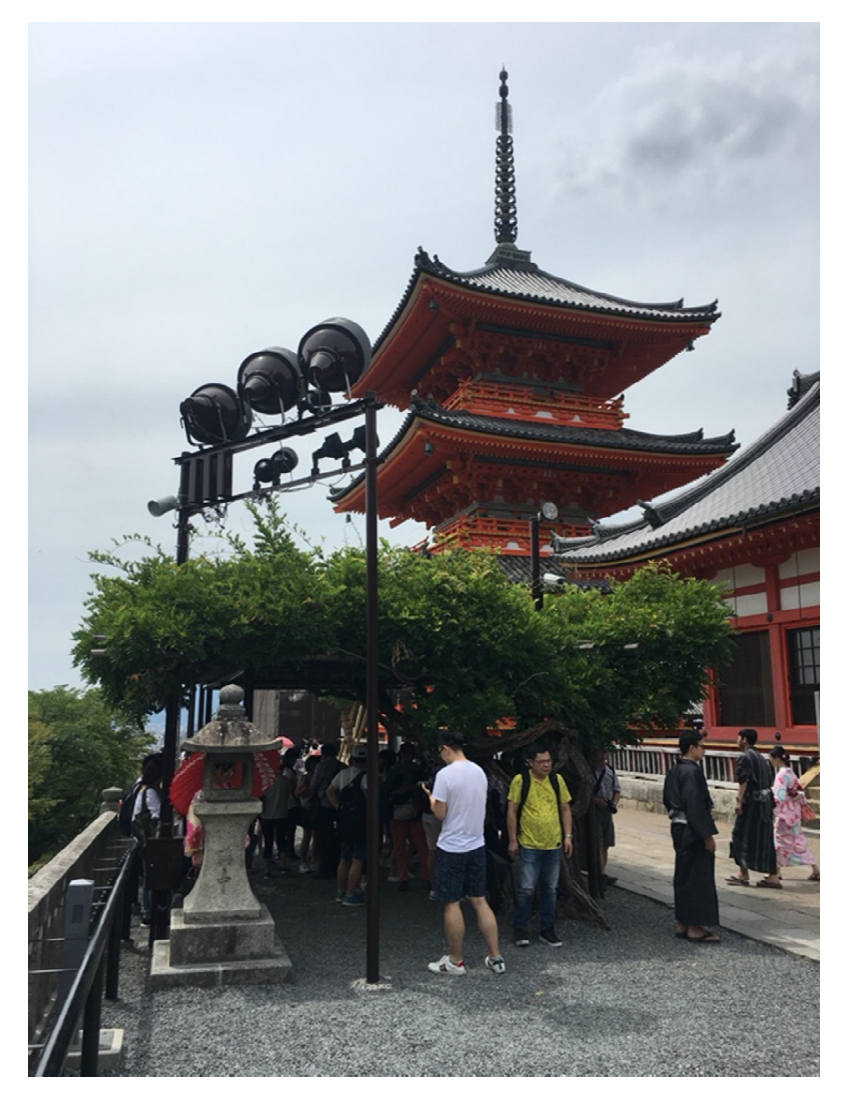

Figure 3. Pagoda and Wisteria Pergola in Kiyomizu-dera

Note: (Copyright C2017 Dexin Chen, all rights reserved used by permission).

\subsubsection{Kiyomizu-dera}

In 780 Kiyomizu-dera was founded by Sakanoweno-Tamu-ramaro. The temple one sees today was a reconstruction by Tokugawa Iyemitsu in 1633 (Figure 3). The main hall was built on a deep ravine with the support of a lot of columns, which was referred to Shinden style (Shūkyōkyoku, 1920). The Kiyomizu complex is a great example of Japanese spatial planning called "sophisticated order". In this complex, the rigid, geometrical setting style of architecture was given up, while the unexpected appearance of the buildings that merged with the nature created a splendid spatial composition (Treib \& Herman, 2003). 


\section{$\Lambda$ Macrothink}

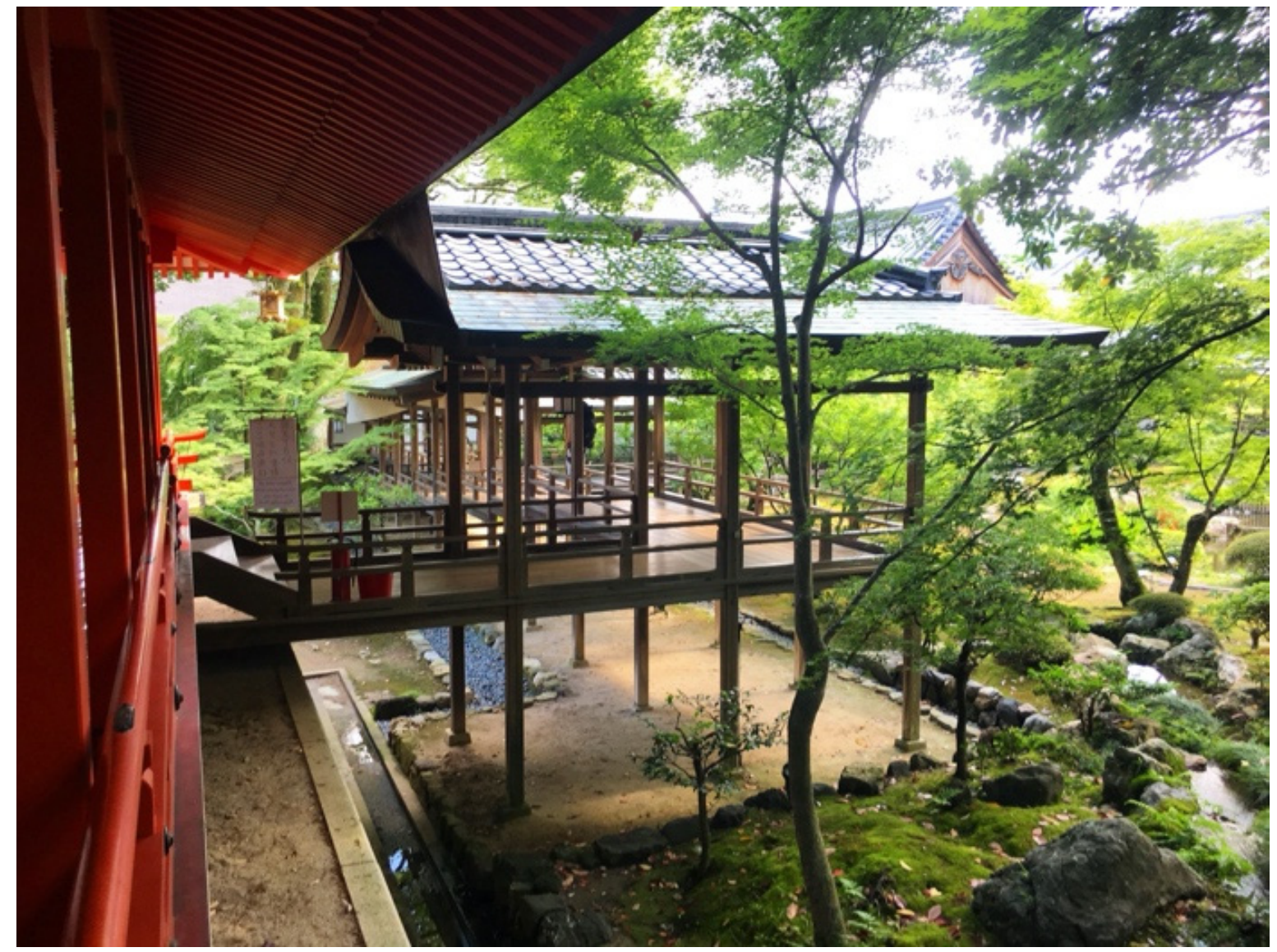

Figure 4. The Lifted Covered Walkway in Daikaku-ji

Note: (Copyright C2017 Dexin Chen, all rights reserved used by permission).

\subsubsection{Daikaku-ji}

In the early Heian period, emperor Saga Rikyu-in built the imperial villa in Kyoto, and Daikaku-ji was originated from the imperial villa of emperor Saga. Daitoku-ji is famous for the oldest artificial garden pond in Japan, Osawa-no-ike Pond, which has perimeter of about eight-hundred meters (Figure 4). It was constructed by emperor Saga to imitate the Lake Dongting in China.

\subsubsection{Tenryu-ji}

Tenryu-ji was built by Shogun Ashikaga Takauji about 1339 (Kamakura period). The garden was designed by a famous garden designer as well as a priest named Muso Kokushi. Muso believed in the value of meditating while viewing gardens. The garden style was both Heian pond style and Chinese (Sung dynasty) style, which produced a sophisticated landscape (Figure 5) (Treib \& Herman, 2003).

The unique design feature of Tenryu-ji garden is the cluster of seven rocks in the pond and the "borrowed scenery". The seven rocks group is raised in the water, it provided strong vertical 


\section{Macrothink Institute ${ }^{\mathrm{TM}}$}

textures that is contrasting the horizontal pond surface. The composition of the seven rocks are highly valued. The reflection of the rocks in the pond lengthened the vertical shape of the rocks, thus the impression of the rock composition is enhanced (Treib and Herman, 2003).

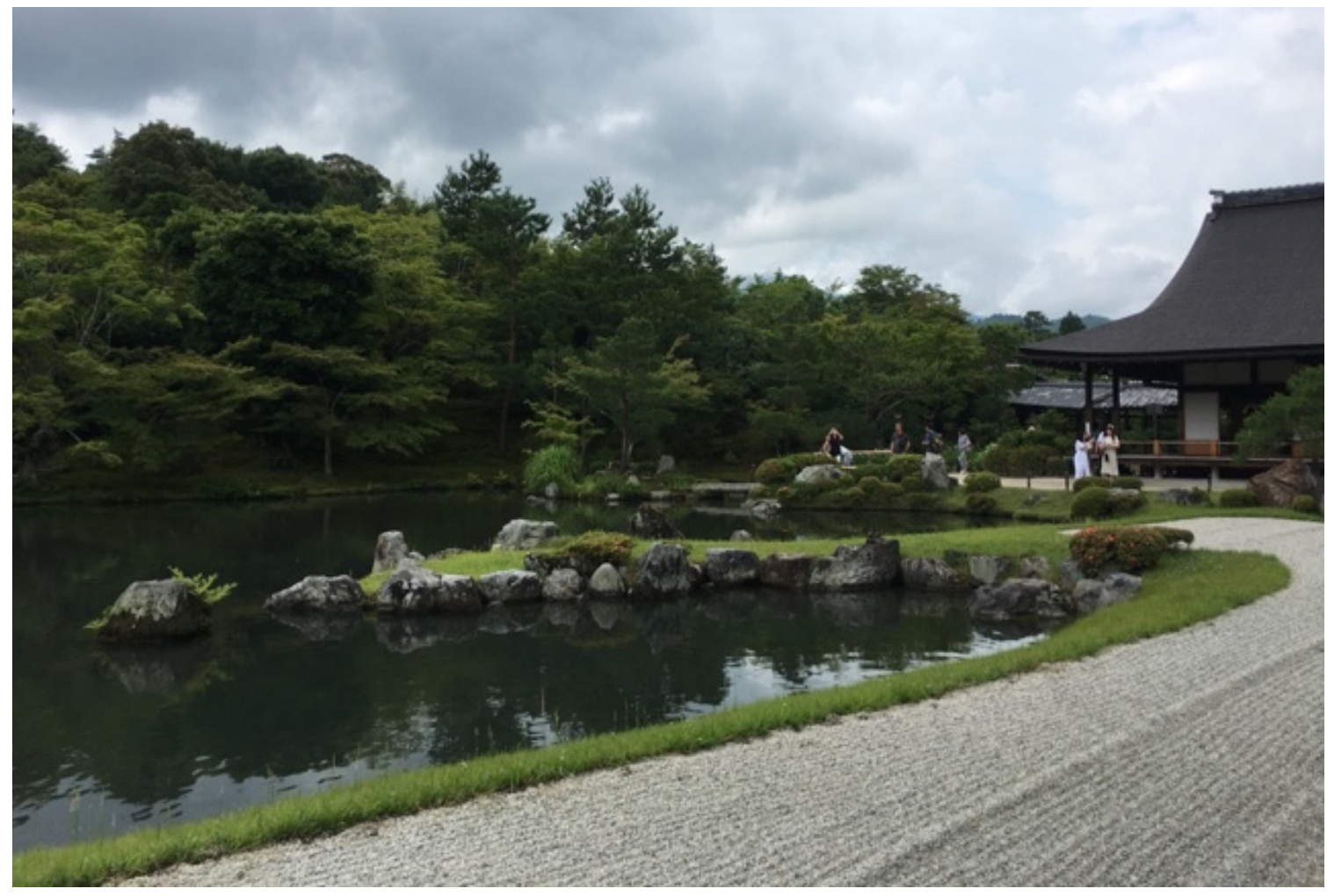

Figure 5. Tenryu-ji Garden

Note: The raked sand design is merged into the view as foreground; the rock groupings suggested the pond edge as midground; the mountain behind is borrowed as background (Copyright (C2017 Dexhin Chen, all rights reserved used by permission).

\subsubsection{Ryoan-ji}

Ryoan-ji rock garden was constructed about 1500, although the original temple building was ruined by fire in 1790's, the rock garden was saved in the blaze (Figure 6). The location of Ryoan-ji was somewhat outside of the ancient Kyoto city plan and remained unknown until the 1930's (Treib \& Herman, 2003). The most famous feature of the Ryoan-ji garden was the dry garden (karesansui). Enclosed by a wall, the dry landscape consists of fifteen rocks placed on a large flat plane of gravel, which reflects Zen Buddhism aesthetic principles of simplicity and the Chinese influence of rocks composition (Lung-Ming 2016). The design was all symbolism, where water and the landscape elements were presented by only the rocks and raked gravel, being the focus of much study (Powell 2002). In this dry garden, except for the moss that surrounds the rock pieces, none of the plant material was used (Treib \& Herman, 2003). Most of the Zen gardens emphasizes the sense of enclosure, for example, the surrounding wall in the 


\section{MInstitute Mach $^{\text {Mn }}$}

International Journal of Culture and History

ISSN 2332-5518

2021, Vol. 8, No. 1

Ryoan-ji garden works as a visual boundary against with the gravel plane (Treib \& Herman, 2003).

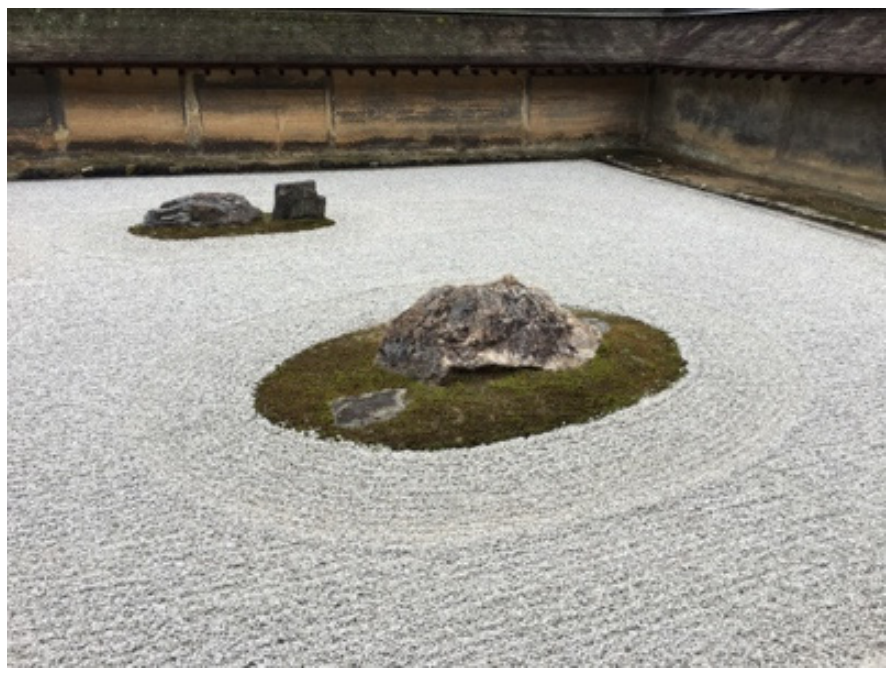

Figure 6. Ryoan-ji

Note: Some of the fifteen rocks in the Zen garden of Ryoan-ji; the rectangular wall brings a sense of enclosure (Copyright (C2017 Dexin Chen, all rights reserved used by permission).

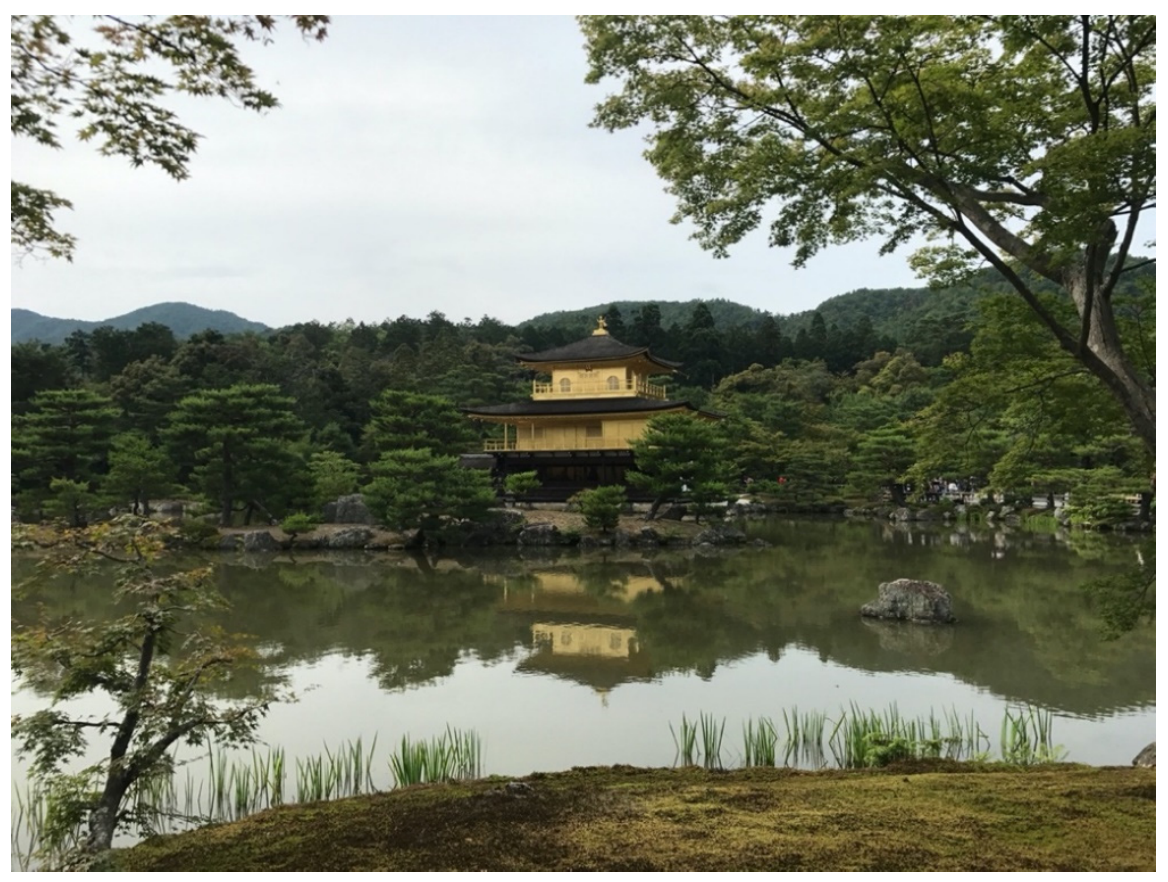

Figure 7. Kinkaku

Note: The golden pavilion and its reflection at the Kinkaku-ji temple grounds (Copyright (C2017 Dexin Chen, all rights reserved used by permission). 


\section{MInstitute Macrothink $_{\text {Ins }}$}

\subsubsection{Kinkaku-ji/Rokuon-ji (The Golden Pavilion)}

The culture of Chinese Song dynasty dominated the Japanese arts in the fourteenth century with the promotion of the third Ashikaga shogun, Yoshimitsu. He organized a group of artists, poets and Zen priests who had been to China to help build a palace complex, aimed to imitate Song style as well as Heian Shinden style. After Yoshimizu's death, this palace complex became a Zen temple (Treib \& Herman, 2003). Few of the original buildings survived during the long history. The large boating pond, rock groupings and extensive plantings, and the pavilion comprised the main view of today's Kinkaku-ji (Figure 7). The pavilion was designed to exhibit the characters learned from Chinese Song style. In 1950, the original unpainted pavilion was destroyed by fire, but an exact copy was constructed soon after the fire. The exterior walls of the pavilion are painted in gold eventually to match its name as the Golden Pavilion (Treib \& Herman, 2003).

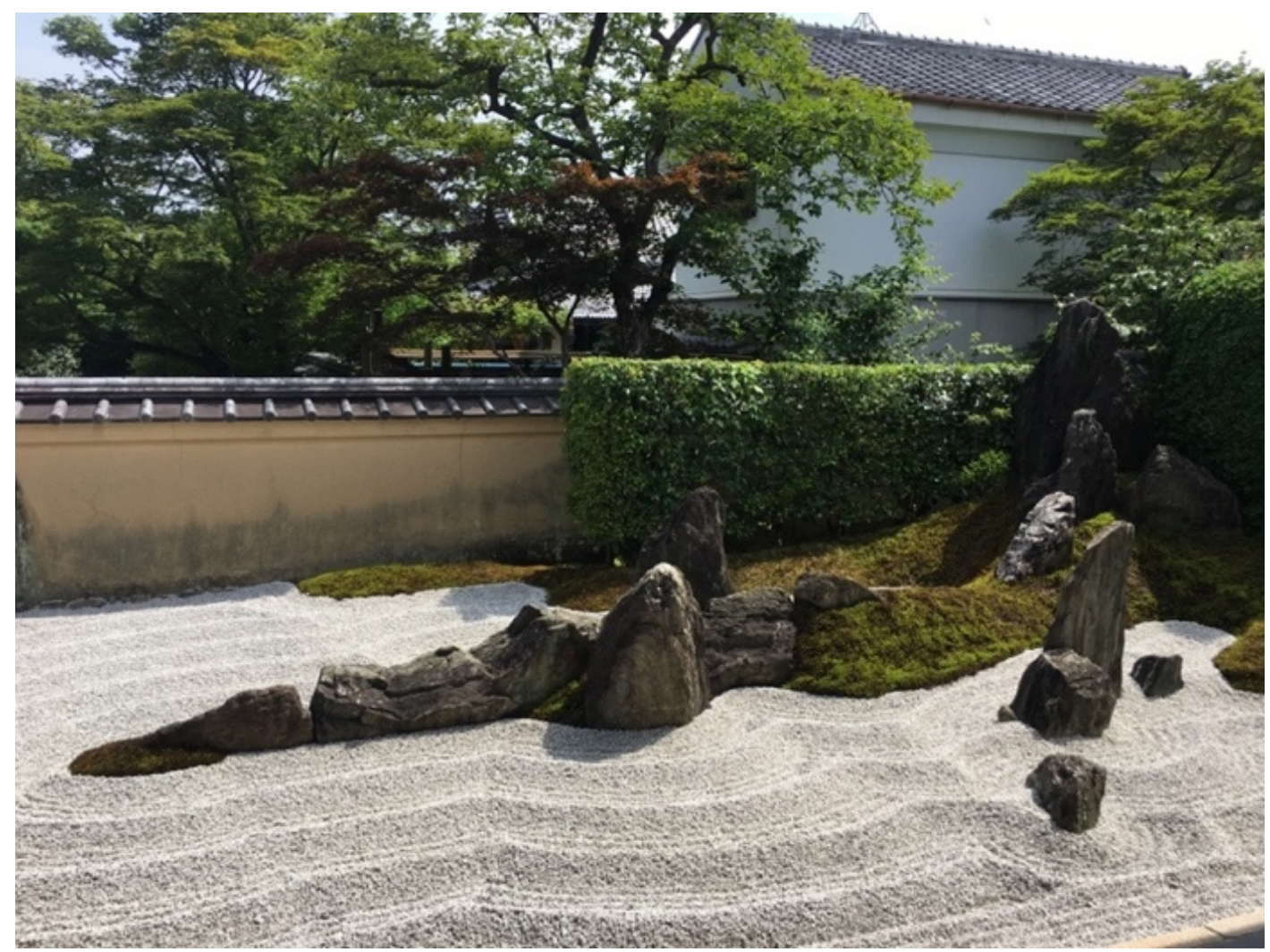

Figure 8. Daitoku-ji

Note: The dry landscape design in Zuihō-in, a sub-temple of Daitoku-ji (Copyright (C2017 Dexin Chen, all rights reserved used by permission).

\subsubsection{Daitoku-ji}

Daitoku-ji is one of the largest Zen temple complexes in Kyoto, which contains many prayer 


\section{N Macrothink Institute ${ }^{\mathrm{TM}}$}

halls and twenty-three sub-temples. Daitoku-ji was founded in 1319 by the priest Shuho Myocho (later called Daito Kokushi), later it was destroyed by fire and war and was rebuilt in 1474 by the priest Ikkyu (Treib \& Herman, 2003). Many of the sub-temples were built in the sixteenth century when Daitoku-ji was supported by the military government (Figure 8). The layout of the entire Daitoku-ji area exhibits the transformation from formal planning to informal planning, where a North-South axis that derived from the traditional formal religious architecture manner of Japan and China underlies the layout of the major buildings, and a cluster of the small sub-temples encircles the main halls. The central main halls are more like the symbolic and visual center of the whole area, in contrast, the sub-temples are treated as private centers of religious ritual. The sub-temples expressed unique characters and Zen Buddhism in the garden design, because the garden was believed to be the most significant part of meditation in Zen practices (Treib \& Herman, 2003).

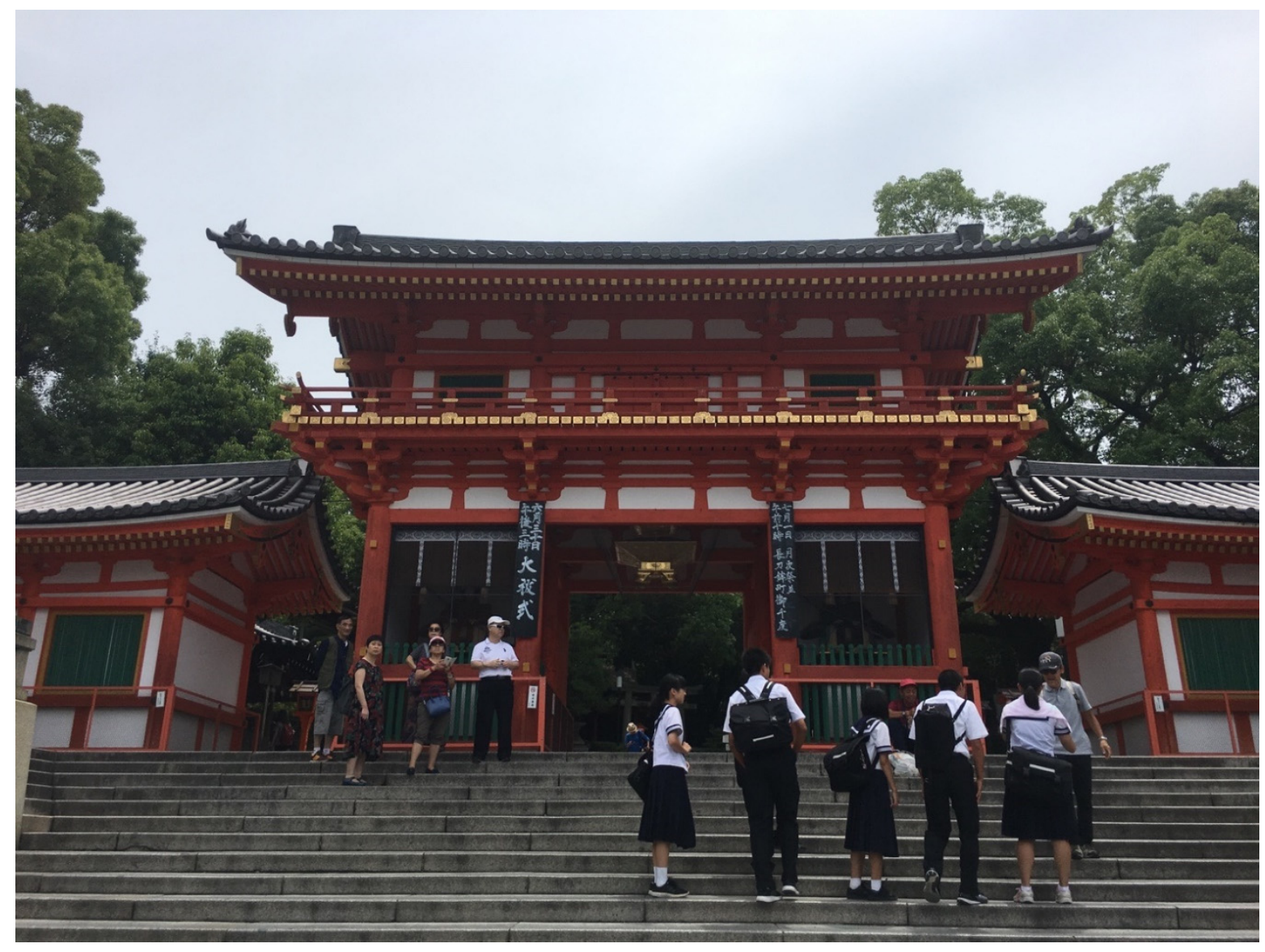

Figure 9. Yasaka Shrine

Note: The main gate with viewing terrace in Yasaka shrine; Chinese characters are used in the informative plaques (Copyright (C2017 Dexin Chen, all rights reserved used by permission). 


\section{Macrothink}

\subsubsection{Yasaka Shrine/Yasaka Jinsha}

In the ninth century, Fujiwara Mototsune turned his residence into the main shrine, the architecture was restored in an imperial palace style. In 1654, Yasaka shrine was reconstructed in old Shinden style according to the old prototype (Figure 9). The main shrine, the small subordinated shrines, the two-storied gate which was built in Kamakura period and the stone Torii which was one of the largest stone Torii in Japan were the main features in this area (Shūkyōkyoku, 1920).

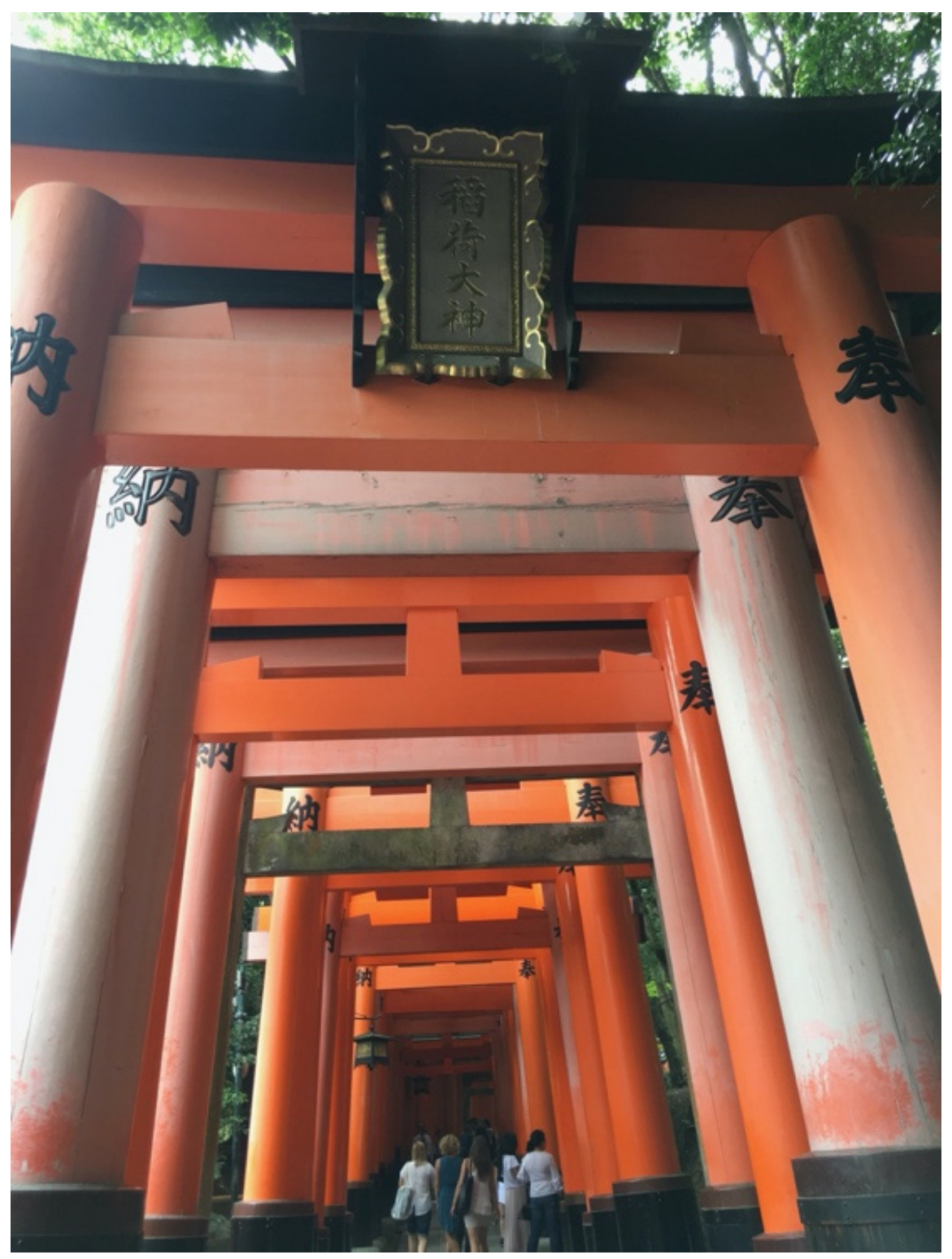

Figure 10. Fushimi-Inari Taisha

Note: Thousands of Torii covered the outdoor pathway in Fushimi-Inari Taisha (Copyright (C2017 Dexin Chen, all rights reserved used by permission). 


\subsubsection{Fushimi-Inari Taisha}

The main hall of Fushimi-Inari Taisha was restored in 1499 in the nagare-zukuri style with an extra-long eave (Figure 10). The red-painted woodwork and the white stucco walls are typical characters of Inari shrines. The five-thousand red Torii together compose a symbolic tunnel of walking trail, which begins from the main hall and climbs up to the Inari mountain. The pathway of red Torii strongly contrasts with the green background of the natural environment, which provides a breathtaking scene. Thousands of fox statues and stone altars that are incised with the names of the gods or animistic believes are placed all over the site, reflects the traditional practices of Inari (Cali \& Dougill, 2012).

\subsubsection{Chinese Gardens}

In this study, the three classical Chinese gardens in Suzhou and five modern Chinese gardens in Xiamen (designed as demonstration gardens by noted contemporary Chinese landscape architects) as described in Xu's study (Xu, 2015) are selected to be study environments for comparison to the ten Japanese gardens. The three traditional Chinese gardens are the Humble Administrator's Garden, Master of Nets Garden, and Lingering Garden. The five modern Chinese gardens are Bamboo Garden, Net. Wet. Garden, Learning Garden, Sugar Cane Garden and Landscape New Wave Garden. Detail information of those Chinese gardens is illustrated in Xu's study (Xu, 2015). The study revealed that the traditional gardens were tightly grouped, being very similar; while, the modern gardens were widely dispersed, where each garden was attempting for originality. Other recent studies in Chinese gardens include Sun, Wang, and Leng (2019) who examined contemporary museum courtyard spaces, Zhang (2017), Lu (2011), Wang, Leng, and Ouyang (2014) who examined modern translation of Chinese gardens, and Yang and Volkman (2010) who compared a variety of Chinese gardens, plazas, and open spaces.

In China there are many traditional and modern gardens that can be selected for study. These eight Chinese gardens were selected because there was published variables about the contents of the gardens and could be readily compared to the Japanese gardens in an ordination. An extensive ordination of the rich abundance from these gardens, would require many future studies and published papers. This study is just the first of many that could be accomplished. All the gardens in the study have been visited and examined in detail by at least one of the coauthors.

\subsection{Research Methodology}

\subsubsection{Variables}

The methodology generates an ordination by examining dimensions composed by a set of design element variables. The first seventy-four design elements are adopted from Xu's (2015) list in 'A cluster analysis comparison of classical Chinese gardens with modern Chinese gardens', the other sixty design elements are selected base on literature review and the author's personal experience in Kyoto. Thus, a list of one hundred and thirty-four design elements in total is generated as below (Appendix 1). The selection and choice of variables is often an area of debate. It usually takes numerous studies before the selection of variables reaches some form of general consensus. 


\subsubsection{Analysis Techniques}

A cluster analysis is applied to identify the similarity or differences by grouping similar items into categories. Following the same steps of Xu's study, a statistical analysis software program called SAS (2012), is used to build principal component analysis (PCA) as the first step of the cluster analysis. By standardizing the original variables, the weight of the variance can be calculated by PCA to help generate the final scores of each studied site. Principal component analysis can simplify the original set of variables into smaller "sets of correlated variables into uncorrelated, independent dimensions" that correspond to some distinguishable latent character revealed by the analysis. The output of PCA would often represent a large percent of the meaningful variance reduced to a few major dimensions (Xu, 2015).

After inputting the data into SAS a set of eigenvalues, corresponding proportion of eigenvalues, means, standard deviations and eigenvectors, which corresponds to the variables, is created for PCA. Means and standard deviations can be used to compute the standard scores of the corresponding variables. Each eigenvalue represents a dimension of the sample data; the eigenvalue that is greater than 1.0 would be defined as the representation of meaningful dimension and used as distinguishable principal component in the cluster analysis. The proportion of each eigenvalue among the whole data set represents its level of significance in the variance of sample data $(\mathrm{Xu}, 2015)$. Usually, cumulative eigenvalues that cover more than sixty to eighty percent of sample data are preferred for further study. In this study, the principal component that correspond to the highest eigenvalue is defined as the first principal component, the second dimension that corresponds to the second highest eigenvalue is defined as the second principal component, and so on. When the meaningful principal components are separated from the original complete set of principal components, the remaining eigenvalues are employed to generate the corresponding eigenvector coefficients. In the output of SAS (version: 9.4 TS Level 1M2, X64_8PRO platform, English, CopyrightC 2002-2012 by SAS Institute Inc., Cary, NC, USA.), eigenvalues can be used to build "linear combinations" of variables, and eigenvector coefficients then can be used to reveal the degree of mutual relationships between the variables and principal components. The variables would be defined as more similar items when the numbers of corresponded eigenvalue coefficients are closer (Xu, 2015). In this research, cluster analysis is done by the equations adopted from Xu's study of Chinese garden comparison $(\mathrm{Xu}, 2015)$. Firstly, standardize the variables by the equation as shown below (Equation 1) (Xu, 2015):

$$
\text { Standard score of a variable }=\frac{\mathrm{X}-\overline{\mathrm{X}}}{\mathrm{SD}}
$$

Where:

$$
\begin{aligned}
& \mathrm{X}=\text { Each Value of Variable } \\
& \overline{\mathrm{X}}=\text { Mean of the Variable } \\
& \mathrm{SD}=\text { Standard Deviation of the Variable }
\end{aligned}
$$

In this equation, mean is the variable's average number of the whole sample data set; standard 
deviation is the number indicated the sample data that are tend to be close to the mean, so that it can quantify the variance of sample data. Secondly, compute the score of each site with standardized variable scores and principal component coefficients corresponding to the variables as the equation shown below (Equation 2) (Xu, 2015):

$$
\begin{aligned}
\text { Site Score } & =\left[\left(\frac{X_{1}-\bar{X}_{1}}{S D_{1}} k_{1}\right)\right]+\left[\left(\frac{X_{2}-\bar{X}_{2}}{S D_{2}} k_{2}\right)\right]+\left[\left(\frac{X_{3}-\bar{X}_{3}}{S D_{3}} k_{3}\right)\right]+\ldots \ldots \\
+ & {\left[\left(\frac{X_{133}-\bar{X}_{133}}{S D_{133}} k_{133}\right)\right]+\left[\left(\frac{X_{134}-\bar{X}_{134}}{S D_{134}} k_{134}\right)\right] }
\end{aligned}
$$

Where:

$$
\begin{aligned}
& \mathrm{X}_{\mathrm{n}}=\text { Each Value of Variable } \\
& \overline{\mathrm{X}}_{\mathrm{n}}=\text { Mean of the Variable } \\
& \mathrm{SD}_{\mathrm{n}}=\text { Standard Deviation of the Variable } \\
& k_{n}=\text { Each Principal Component Coefficient }
\end{aligned}
$$

Finally, a computed site score of each selected garden on a scatter graph in Excel (Microsoft ${ }^{\circledR}$ Excel for Mac, version: 15.32), where each site score can be plotted by and located upon the various dimensions. For example, in a two-dimensional scatter graph, site scores of one principal component can be located by the horizontal axis, while site scores of another principal component set can be located by the vertical axis. In this way, site scores of two principal components can be reviewed directly through their location on the scatter graph. When the points of the corresponding site scores are clustered together on this scatter graph, according to the definition of the principal components, these corresponding sites would be defined as more similar than other sites. Eigenvectors coefficients can be used to explain the visually detected linear combinations of variables in the scatter graphs; the highest and lowest eigenvalue coefficients are considered most responsible to the coordinates of the site scores. Then, address the corresponding variables of the highest and lowest eigenvalue coefficients, so that the explanation of the data variance can be suggested by these distinctive variables. Thus, a conclusion of the site comparison can be generated by the cluster analysis to address their similarities or differences in the design elements and principles (Xu, 2015). This approach is similar to Li et al. (2020) who ordinated various designers and painters according to a list of variables.

\section{Results and Discussion}

\subsection{Results}

As shown in Table 1, only the first seventeen principal component eigenvalues are greater than 1.0, which means they are most useful to explain the variance. The first three principal component eigenvalues had cumulatively covered 70.77 percent of the variance in the sample data, where the first principal component covered 43.2 percent of the variance. The fourth to the seventeenth principal components are greater than 1.0 but their proportions are much 
smaller than the first three principal components, they can be examined for future study. Therefore, only the first three principal component eigenvalues are selected for the calculating principal component coefficient in this study.

Table 1. Principal Component Analysis Eigenvalues of the Covariance Matrix from the SAS Software Program

\begin{tabular}{|c|c|c|c|c|}
\hline & Eigenvalue & Difference & Proportion & Cumulative \\
\hline 1 & 56.1662056 & 29.375329 & 0.432 & 0.432 \\
\hline 2 & 26.7908766 & 17.7501596 & 0.2061 & 0.6381 \\
\hline 3 & 9.040717 & 0.6477713 & 0.0695 & 0.7077 \\
\hline 4 & 8.3929457 & 3.4082898 & 0.0646 & 0.7722 \\
\hline 5 & 4.9846559 & 0.4160248 & 0.0383 & 0.8106 \\
\hline 6 & 4.5686311 & 0.7018803 & 0.0351 & 0.8457 \\
\hline 7 & 3.8667507 & 0.8990064 & 0.0297 & 0.8755 \\
\hline 8 & 2.9677444 & 0.5141437 & 0.0228 & 0.8983 \\
\hline 9 & 2.4536007 & 0.3388601 & 0.0189 & 0.9172 \\
\hline 10 & 2.1147406 & 0.2062816 & 0.0163 & 0.9334 \\
\hline 11 & 1.908459 & 0.3155289 & 0.0147 & 0.9481 \\
\hline 12 & 1.5929301 & 0.1353563 & 0.0123 & 0.9604 \\
\hline 13 & 1.4575738 & 0.0209401 & 0.0112 & 0.9716 \\
\hline 14 & 1.4366337 & 0.2932455 & 0.0111 & 0.9826 \\
\hline 15 & 1.1433882 & 0.2990471 & 0.0088 & 0.9914 \\
\hline 16 & 0.8443411 & 0.5745355 & 0.0065 & 0.9979 \\
\hline 17 & 0.2698056 & 0.2698056 & 0.0021 & 1 \\
\hline
\end{tabular}


In the output of PCA as shown in Table 2, none of the corresponding coefficients of the principal components scores are larger than 0.4 or smaller than -0.4 , which means the variance of the sample data is determined by many distinguishable variables together, instead of a few outstanding distinctive variables. The variables with the highest and lowest numbers in the principal component coefficients are suggested to be the distinguishable variables and would be later used for suggesting the meaning of the dimensions in the final scatter graphs $(\mathrm{Xu}$, 2015). The largest coefficient of principal component 1 is around 0.13 , the smallest coefficient is around -0.08 . In the second and third principal components, the largest coefficients are around 0.15 , the smallest coefficients are around -0.15 . The eigenvalues coefficients of the first three principal component analysis are later used for calculating the site scores of the eighteen selected sites by Equation 2. Therefore, a table of site scores corresponding to the first three principal components is generated as shown in Table 2. There is no over-arching variable that defines any of the first three principal component dimensions. However, there are related sets of variables for each dimension, which are proposed in the following discussion.

To glean more insight into the results from the principal components, a multi-dimensional model is built by three two-dimensional plots with each two-component combination of the selected principal components. After all site scores of the first three principal components are calculated (as presented in Table 2), these scores are arranged in three groups that name after the order of the principal components: the first and the second principal component (Figure 11); the first and the third principal component (Figure 12); the second and the third principal component (Figure 13). The site scores are located on Excel scatter graphs by the following approach: in the first group, use the first principal component to locate the sites on horizontal axis and the second principal component to locate the sites on vertical axis, and apply the same process to the other two groups. In this way, three scatter graphs are generated for the cluster analysis as shown in Figures 11, 12,13. Dimension of principal component 1 is suggested to be named as "traditional oriental garden symbolic features as opposed to modern non-Asian garden features", while the dimension of principal component 2 suggests "simplicity verses complexity". The third principal component stresses "hardscape verses softscape." The three plots illustrate the relationships between the gardens.

Table 2. Site Scores in the First Three Principal Components

\begin{tabular}{cccc}
\hline Name of the Study Sites & PRIN 1 & PRIN 2 & PRIN 3 \\
\hline Humble Administrator's Garden & 2.878997851 & 11.47605414 & -0.070171415 \\
Master of the Nets Garden & 2.026469535 & 10.25661709 & -0.715462914 \\
Lingering Garden & 2.27319477 & 11.28467025 & -0.630696698 \\
Bamboo Garden & -10.99618606 & -0.581932239 & 3.651821376
\end{tabular}


Net. Wet. Garden

$-13.23501174$

$-10.02816392$

$-12.53322977$

$-10.62584938$

5.534979673

6.323252889

5.49021076

5.628313554

4.004667988

5.410253068

6.419067306

5.824693684

1.791856137

3.812484892
$-1.513331994$

$-6.931290784$

6.091662956

$-5.235318345$

4.920699942

$-0.247457737$

0.580402245

0.178561372

0.560982113

$-0.261490675$

$-0.503209831$

$-0.426469414$

0.444542243

$-1.417633315$

$-1.044909662$

Fushimi-Inari Taisha

$-0.362192459$ 


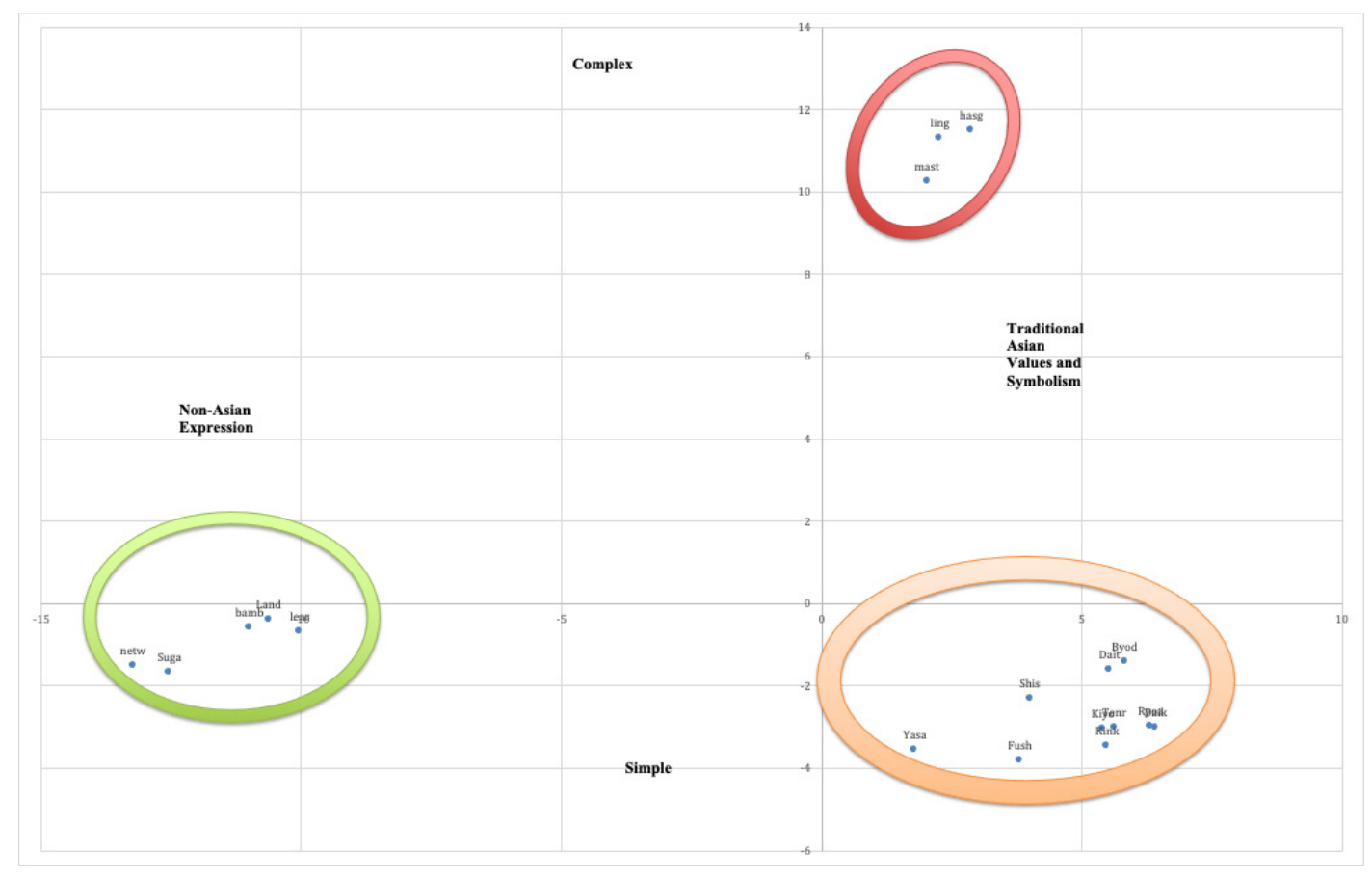

Figure 11. Plot of First and Second Dimension

Note: Principal Component 1 horizontal axis (modern left, traditional features right) and Principal Component 2 vertical axis (complexity top, simplicity bottom); the traditional Chinese gardens are in the upper right (red oval); the traditional Japanese gardens are in the lower right (orange oval) and the modern Chinese gardens are on the left (green oval).

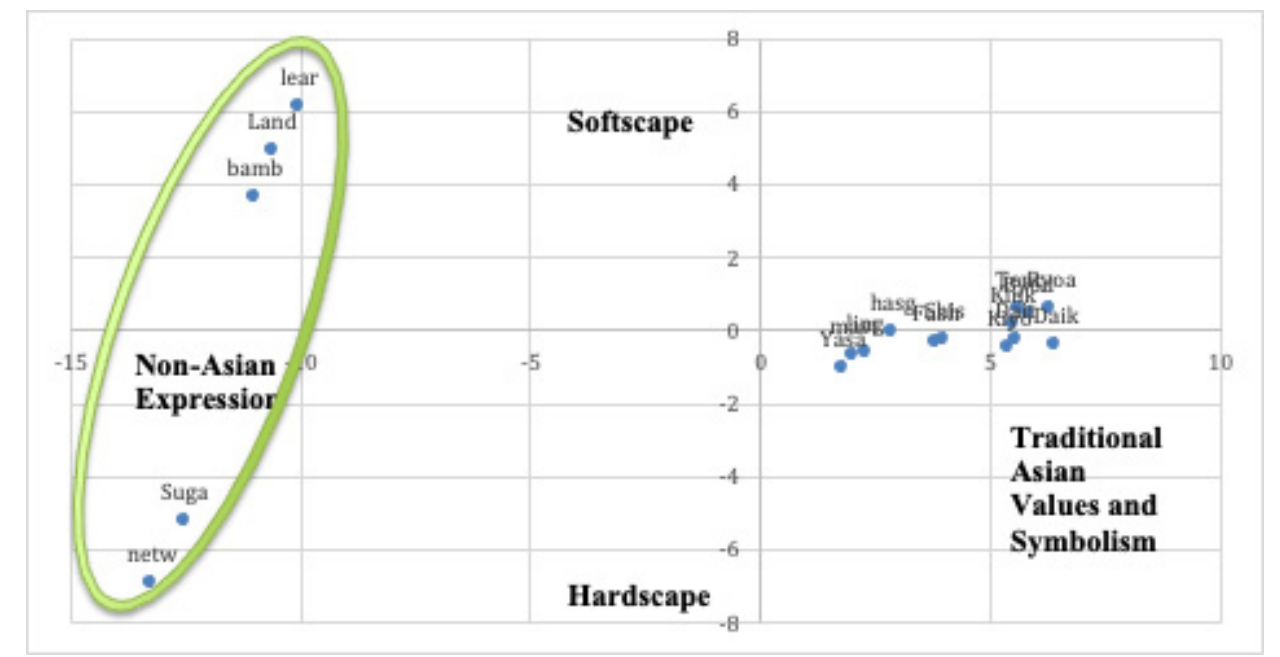

Figure 12. Plot of the First and Third Dimensions

Note: Principal Component 1 horizontal axis (modern left, traditional features right) and Principal Component 3 vertical axis (softscape top, hardscape bottom). The traditional Chinese and Japanese gardens are clustered on the right; the modern Chinese gardens are on the left (green oval). 


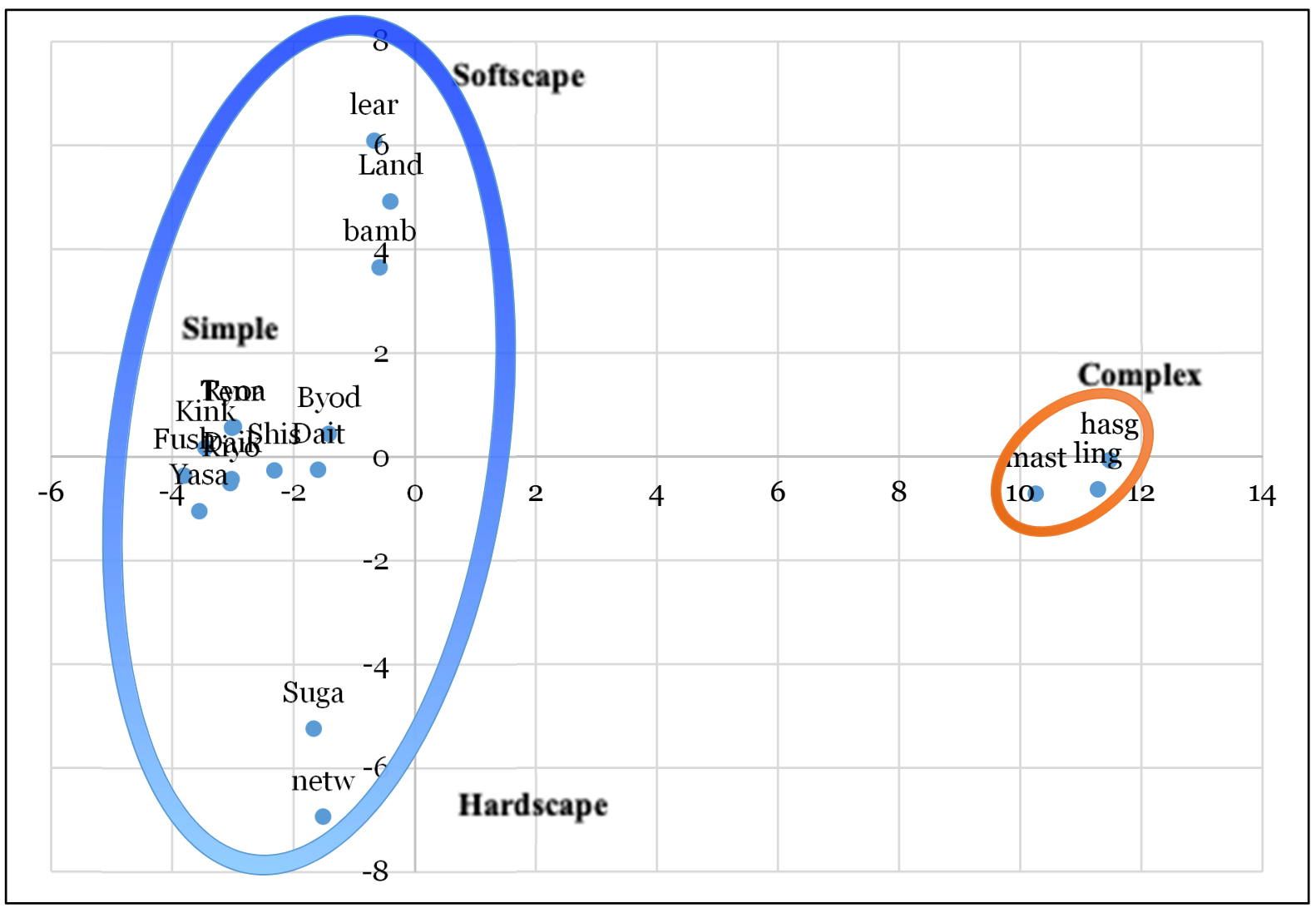

Figure 13. Plot of the Second and Third Dimensions

Note: Principal Component 2 horizontal axis (simplicity left, complexity right) and Principal Component 3 vertical axis (softscape top, hardscape bottom); the traditional Japanese gardens are on the center-left (center of blue oval); the traditional Chinese gardens are on the centerright (orange oval); modern Chinese gardens are on the top and bottom left (blue oval).

\subsection{Discussion}

\subsubsection{Interpretation of the Dimensions and Plots}

The contents of the modern Chinese gardens are quite different than the historic Oriental gardens. The traditional Chinese gardens are in a tight clustered group while the Japanese gardens are more spread apart. This may be because the Japanese gardens are somewhat more diverse in character where each Japanese garden may present a more unique identity. Social pressures in Japan to limit design expression may have been less constrained than in China. The plots of the traditional Chinese gardens suggest that the expert opinion of garden scholars concerning the close similarity of these environments is supported. Meanwhile, the modern Chinese gardens, without strong dynastic pressures to conform and not deviate, suggests that modern gardens are striving for uniqueness and are much more widely spread and scattered on a graph. Compared to the complexity of the traditional Chinese gardens, the modern Chinese gardens and Japanese gardens contain relative simplicity. The simplicity may be an indirect expression of construction and maintenance costs concerning a garden, and also sensibilities 


\section{Macrothink}

addressing how busy and complicated a garden should be. The modern Chinese gardens span both hardscape and softscape extremes, where some landscapes contain mostly plants, other landscapes contain an abundance of walls and paving. The Oriental gardens are a balance of softscape and hardscape in composition.

The study assists in understanding the relative similarities and differences amongst the three groups of gardens. However, this study is a somewhat new way of interpreting gardens and is dependent upon what variables are selected and which gardens are studied. It is a fresh look at the interpretation of the gardens, but certainly not a definitive study. Experts without quantitative analysis my derive similar conclusions through heuristic opinions; but the approach in this study allows for repeatability and a more quantitative approach. The options and choices to investigate gardens with this approach are endless. There are many more gardens to investigate.

\subsubsection{Applications in Michigan and Vancouver}

Comparison to other gardens is possible by employing the results of the study. The investigation examined two Asian gardens in North America: the Richard and Helen Devos Japanese Garden located in the outskirts Grand Rapids, Michigan (Figure 14) (Peregoy, 2015) and the Dr. Sun Yat Sen Classical Chinese Garden in Vancouver, British Columbia, Canada (Whysall, 2015).

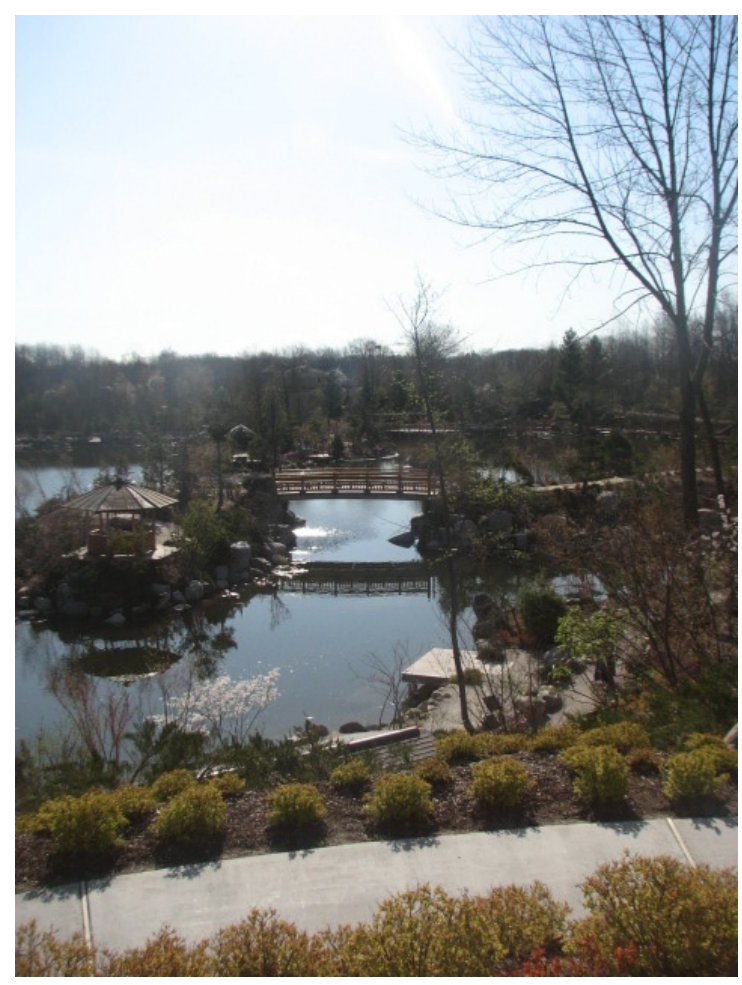

Figure 14. Richard and Helen Devos Japanese Garden

Note: (Copyright (C2016 Jon Bryan Burley, all rights reserved used by permission). 


\section{Macrothink}

International Journal of Culture and History

ISSN 2332-5518

2021, Vol. 8, No. 1

The Richard and Helen Devos Japanese Garden opened in 2015, in the Frederick Meijer Gardens and Sculpture Park. The Japanese styled garden was designed by Hoichi Kurisu and Kurisu Interational (Peregoy 2015). Kurisu has also designed notable Japanese inspired gardens in Oregon, Illinois, and Florida. The garden covers approximately 3 hectares of land and cost 22 million American dollars to construct (Associated Press, 2015). The garden is a small public stroll garden as opposed to a true temple or residential garden. The garden is positioned in a climate colder than the gardens in Kyoto, limiting the vegetation palette that would be found in Kyoto.

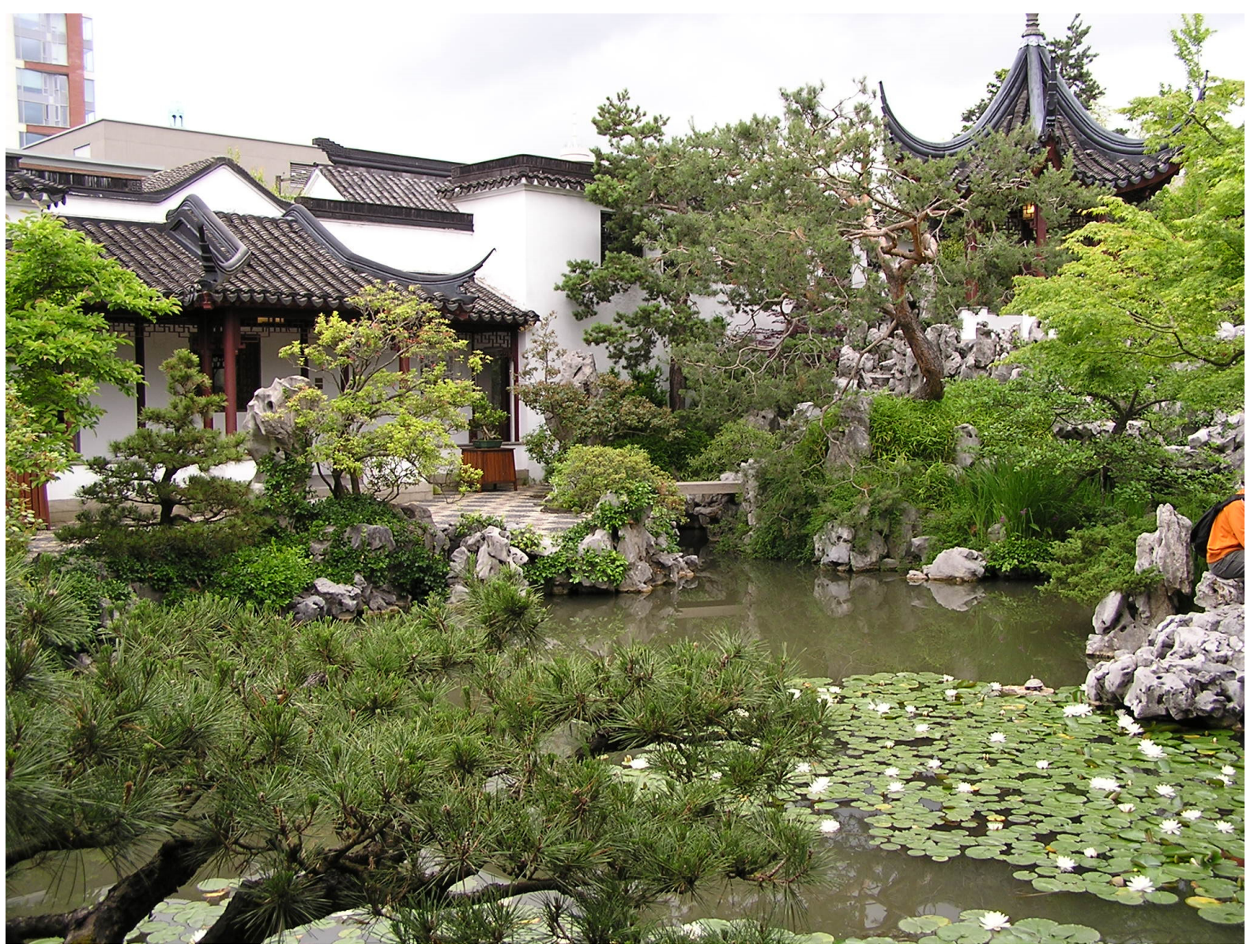

Figure 15. Dr. Sun Yat Sen Classical Chinese Garden

Note: (Copyright (C2006 Jon Bryan Burley, all rights reserved used by permission).

The Dr. Sun Yat Sen Classical Chinese Garden was built in 1985, by landscape architecture artisans led by Xiao Lin Feng from Suzhou, Jiangsu, P. R. of China (Whysall, 2015) with the architect Wang Zu-Xin also contributing (Wilson, 2019), both from the Suzhou Institute of Landscape Architecture Design Company (Figure 15). The garden is inspired from traditional Chinese gardens in Suzhou, Shanghai, and Beijing (Wilson, 2019). The Vancouver garden is a public garden with an entrance fee, as opposed to true residential origins. The Suzhou gardens 
also have an entrance fee at this time.

Both gardens were evaluated with the variables employed in this study and then computed with Equation 2. The Richard and Helen Devos Japanese Garden had the following scores for the first three dimensions: $-1.17011,0.089758,1.5361$. The Dr. Sun Yat Sen Classical Chinese Garden contained the flowing values for the first three dimensions: $3.8205,5.3772,1.513$. The two modern gardens based upon traditional values are plotted in Figures, 16, 17, and 18. In a graph of the first two dimensions (Figure 16), the Richard and Helen Devos Japanese Garden resides on the outer edges of a cluster formed by the Japanese gardens. The Dr. Sun Yat Sen Classical Chinese Garden resides outside the tight cluster of the classical Chinese gardens from Suzhou, between the Japanese cluster of gardens from Kyoto and the Chinese gardens from Suzhou.

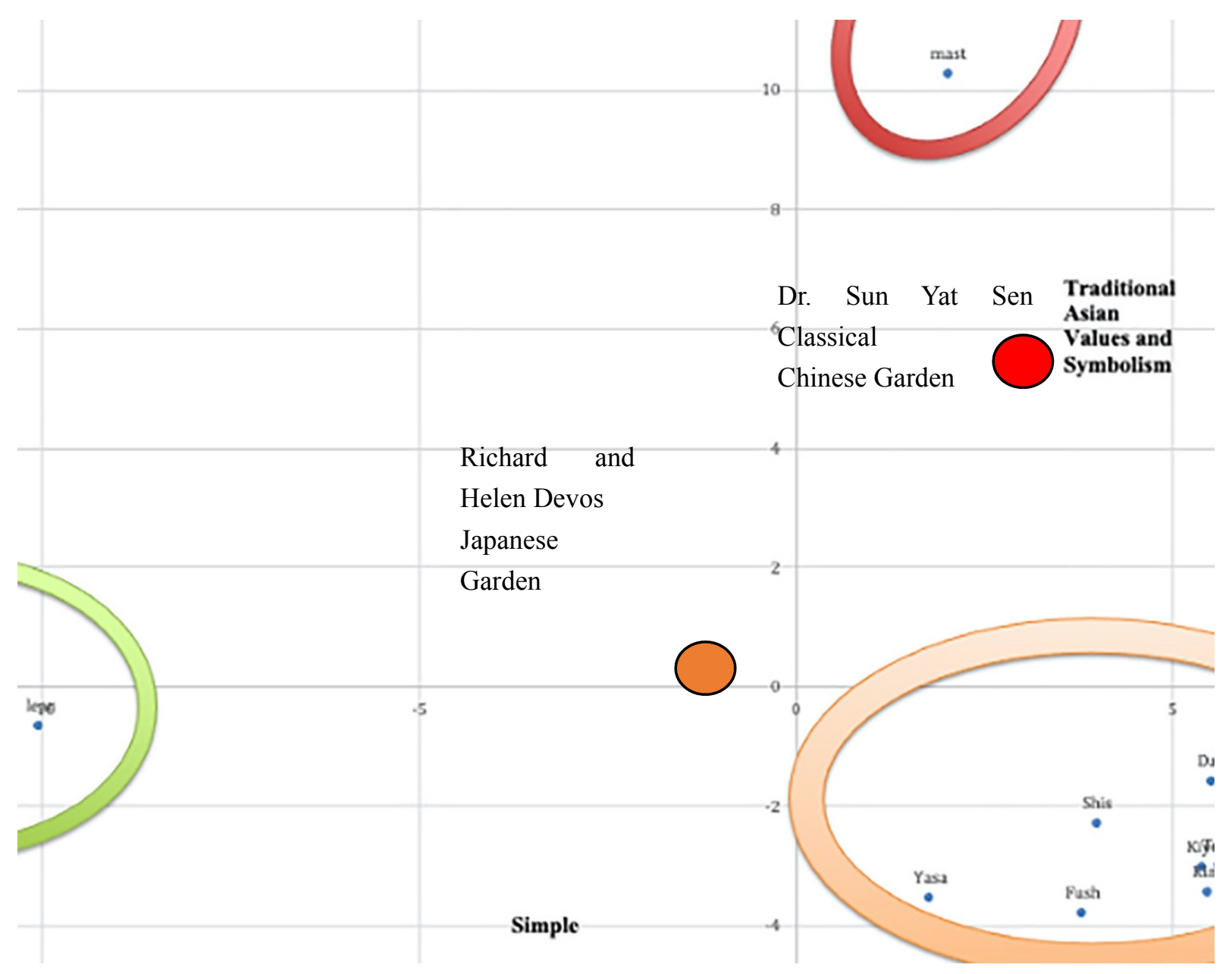

Figure 16. Location of North American Gardens on the First Two Dimensions

Note: The location of the Richard and Helen Devos Japanese Garden (orange circle) and the Dr. Sun Yat Sen Classical Chinese Garden (red circle) on the first and second dimensions derived from this study. 


\section{MInstitute ${ }^{\text {Mink }}$}

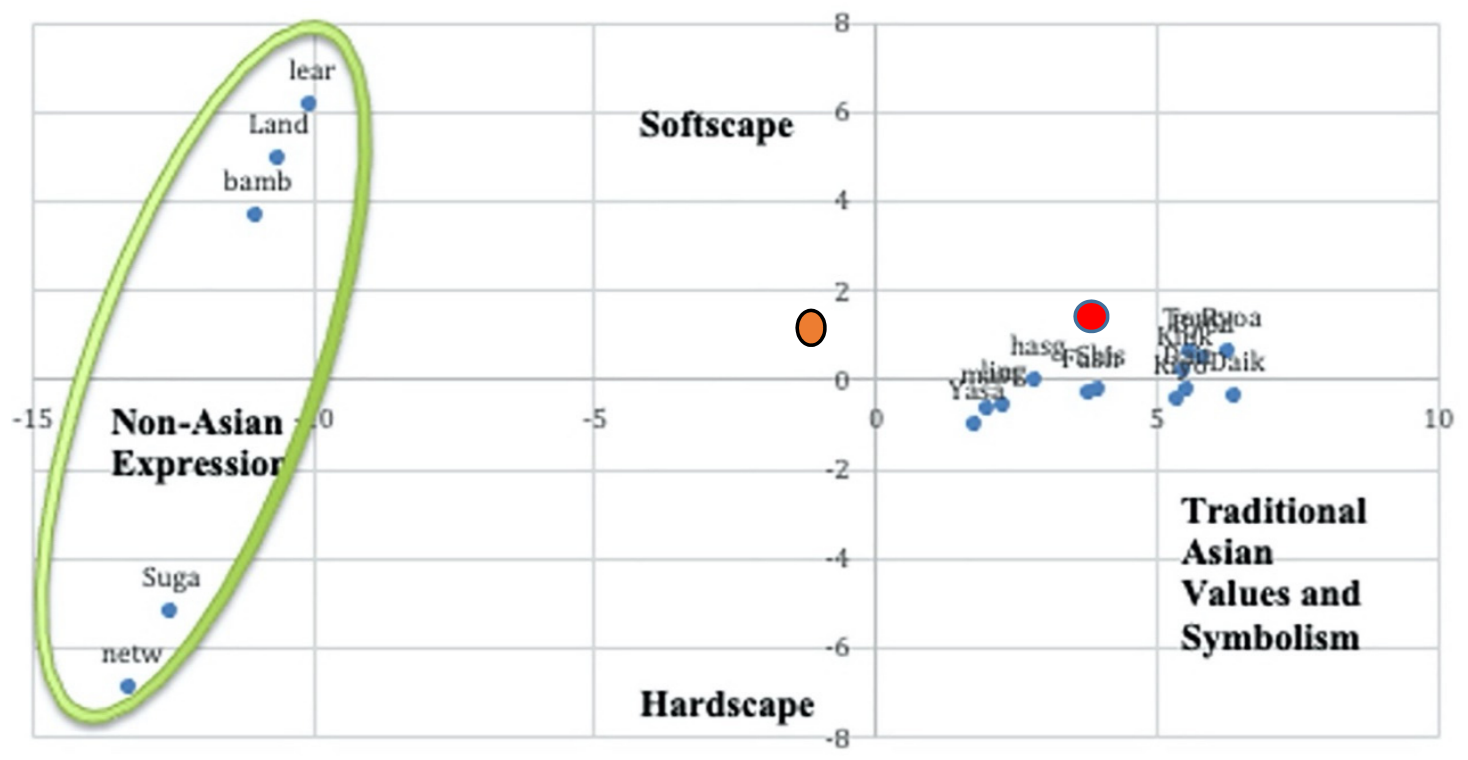

Figure 17. Location of North American Gardens on the First and Third Dimensions

Note: The location of the Richard and Helen Devos Japanese Garden (orange circle) and the Dr. Sun Yat Sen Classical Chinese Garden (red circle) on the first and third dimensions derived from this study.

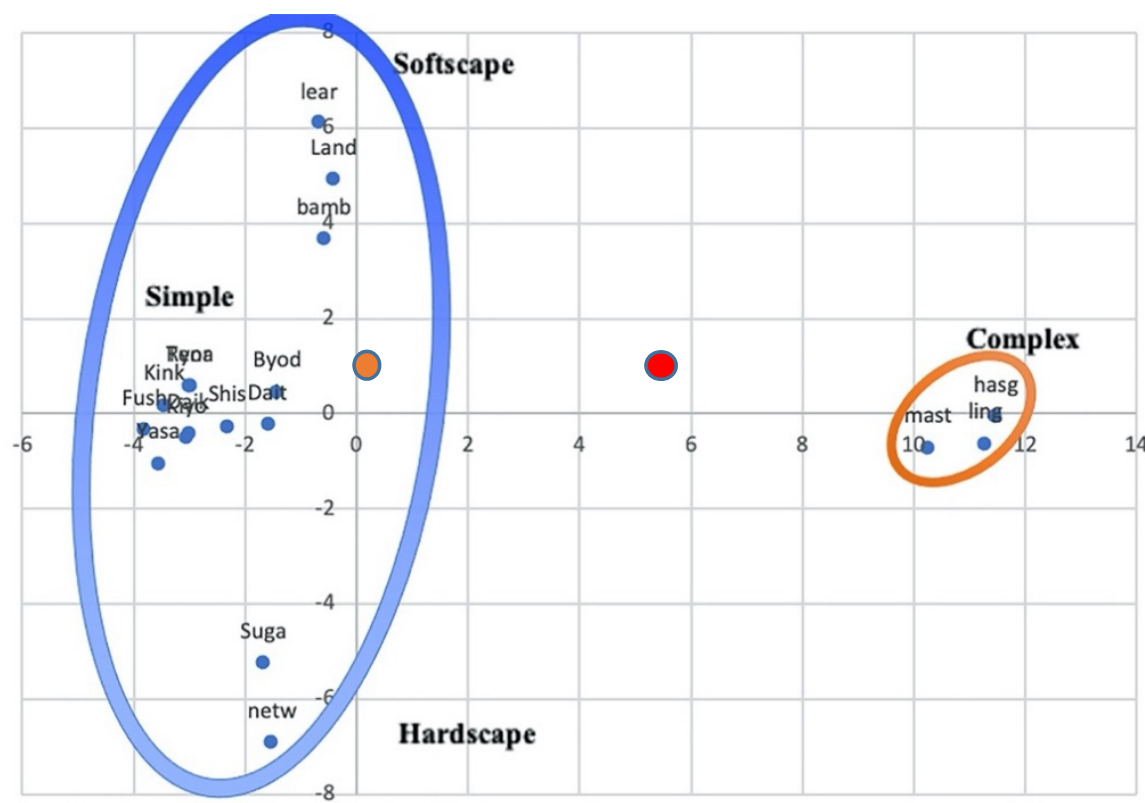

Figure 18. Location of North American Gardens on the Second and Third Dimensions

Note: The location of the Richard and Helen Devos Japanese Garden (orange circle) and the Dr. Sun Yat Sen Classical Chinese Garden (red circle) on the second and third dimensions derived from this study. 
On a graph of the first and third dimensions (Figure 17), the Richard and Helen Devos Japanese Garden and the Dr. Sun Yat Sen Classical Chinese Garden reside in the cluster of traditional Asian gardens. While in a graph of the second and third dimensions (Figure 18), the Richard and Helen Devos Japanese Garden resides in a cluster of simple gardens. In contrast the Dr. Sun Yat Sen Classical Chinese Garden resides outside both the simple cluster and the tight complex cluster of the classical Chinese gardens from Suzhou.

Both of the gardens reside upon locations between hardscape and softscape, typical of the traditional Asians gardens in this study, meaning they retain a blend of hardscape and softscape found in the traditional gardens. In addition, both gardens contain the traditional symbolism and materials found in traditional Asian gardens. However, the garden in Vancouver retains a middle position between the highly complex gardens of Suzhou and the simple gardens of Kyoto. The garden in Vancouver is actually a public display and education garden/park (with an entrance fee), not truly derived from a residential setting. This may account for some of reason it occupies a middle complexity position, containing design values blended with the residential garden traditions of China and the educational and experiential expectations expressed in the West. The garden was designed by the same designers who relatively recently restored the famous gardens in Suzhou from pictures in the 1930s. They took this expertise to develop an experience for Westerners. The garden in Vancouver is not meant to be a full replication of a Suzhou garden, but rather borrowed essential ideas from Suzhou and present them in a Western setting. In many ways it is a practical fusion of ideas based heavily upon Suzhou precedents with the realities of creating a garden in a large west coast modern urban city in North America. Therefore, it is not surprising the garden does not occupy the tight cluster of the Suzhou gardens.

The results suggest that the Richard and Helen Devos Japanese Garden is tending towards containing less traditional design components than the traditional gardens in either Kyoto or Suzhou. This may be in part because the types of materials found in lower Michigan, where there are few if any angular rocks, lacking abundant opportunities for borrowed scenery, the need for winter hardy plant materials, a lack of a shrine or temple, missing a strong conceptual landscape statement/story, and the simple mass planting style evident in corporate and North American landscapes. The garden concentrates upon objects and naturalistic arrangement of these objects; but, the garden is limited in some of the framework organization mentioned by Chen and Burley (2018). This does not mean it is a poor garden, but rather it is a garden inspired and directed by many Japanese features, being very pleasant to experience; rather, it drifts from the garden types in found in Kyoto, and occupies an ordination space unique unto itself. "In 2018, I went to the Richard and Helen Devos Japanese Garden with a Japanese colleague of mine to visit the garden. He seemed surprised and impressed when I could identify authentic and less authentic features in the garden. He also told me many other less than authentic features of the garden too. He felt like some areas of the garden were more like a maple collection arboretum than a true Japanese stroll garden. Still, he was very proud that there was a version of such a garden in Michigan, and greatly enjoyed the experience. He was most impressed with the entrance gate, where the exposure of fasteners such as nails and screws are not evident nor revealed. He indicated a true craftsman built the gate. In Michigan on another 


\section{Macrothink Institute ${ }^{\mathrm{TM}}$}

spring day, we visited the Hidden Lake Gardens, operated by Michigan State University, were we spent time in the Harper Collection of dwarf and rare conifers, a world class collection, possibly the best in the United States, designed in the 1980s by Sam Lovall, ASLA. He found this garden an unexpected surprise and highly inspirational, reminding him of plant collections at Kew Gardens and Stourhead, United Kingdom." reflected Dr. Burley. Both the Richard and Helen Devos Japanese Garden and the Harper collection (Courtney \& Elardo, 2012) at Hidden Lake Gardens (Figure19). have become destinations for garden enthusiasts in Michigan. In this study the Harper Collection was not ordinated in the plots (Figures 11, 12, 13), but would be suspected of residing in the upper left corner of Figure 12.

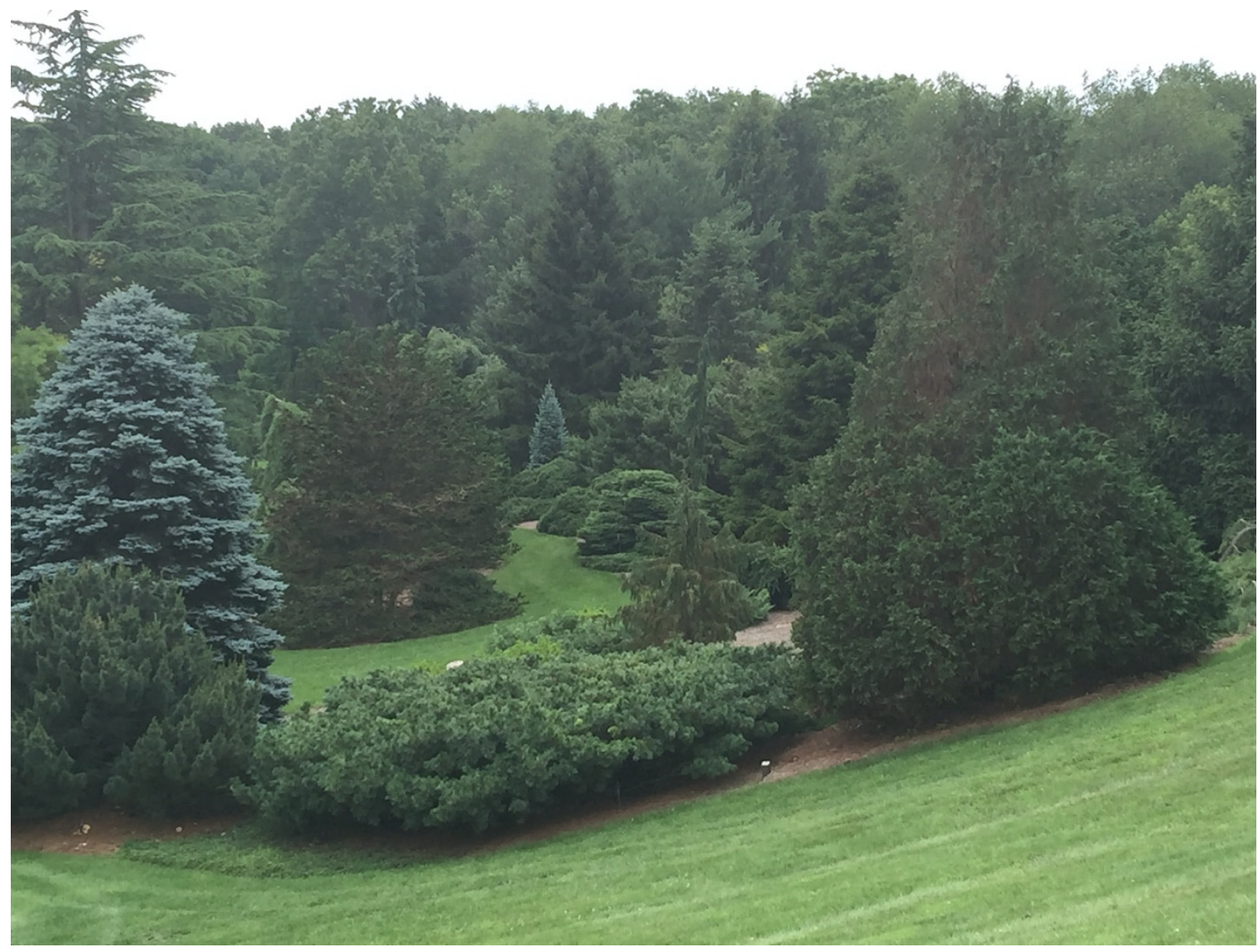

Figure 19. Harper Collection, Hidden Lake Gardens

Note: The design is an arboretum collection (with plant labels), organized with English Landscape School and Asian sensibilities, somewhat similar to the modern softscape gardens in the study reported by Xu et al. (2016). The design is representative of French, Dutch, and English propensity to collect pants from around the world, the more rare, unusual, or spectacular the plant, the better it is received (Wang \& Burley, 2009). Many of the plants would be rarely if ever used in an Asian garden because they have no cultural meaning or historical significance to the Asian garden visitor (Copyright (C2015 Jon Bryan Burley, all rights reserved used by permission). 
The approach employed in this study allows one to examine broad similarities and differences between some Asian gardens and gardens designed outside Asia that are based upon Asian design principles. The results are not definitive but do reinforce notions and supply empirical evidence that were only expressed before by expert opinion.

\section{Conclusion}

Traditional Japanese gardens evolved from Chinese garden traditions. They share a common theme, being inspired from nature, yet over time, Japanese gardens evolved into their own unique expressions. The results of this study suggest that indeed Japanese gardens are simplistic (as suggested by experts and respondents), contain Asian values, and occupy a middle zone between softscape and hardscape landscapes. While traditional Chinese gardens are clustered very closely in similarity, Japanese gardens are more divergent in expression. In contrast to Japanese gardens, traditional Chines gardens are complex, but containing Asian values similar to Japanese gardens, and also occupy a middle zone between softscape and hardscape environments. Compared to the traditional Asian gardens, the modern Chinese garden examples reflect some non-Asian design values. Compared to traditional Chinese gardens, modern gardens are also relatively simplistic, but span the broad diversity along a softscape to hardscape dimension. While the modern Chinese gardens studied in this investigation were created by Asians, they reflect a different sensibility and greater diversity than traditional gardens from both Japan and China. Many more such empirical comparisons and clustering could be accomplished across the many expression of Asian gardens.

\section{Acknowledgements}

The authors of this study wish to acknowledge Yiwen $\mathrm{Xu}$ from the China Shanghai Architectural Design \& Research Institute Company, for supplying information concerning the Suzhou Institute of Landscape Architecture Design Company and the Dr. Sun Yet San Classical Chinese Garden in Vancouver, British Columbia, Canada.

\section{References}

Associated Press. (2015). Japanese garden featuring sculpture is opening in Michigan. AP News. New York, New York: Associated Press, 11 June. Retrieved from https://apnews.com/article/grand-rapids-japan-michigan-gardening-archivef4c444feb05049e5b4c687ea88f4a3ab

Bai, Y., Chang, Q., Guo, C., Burley, J.B., \& Partin, S. (2016). Neo-sol productivity models for disturbed lands in Wisconsin and Georgia, USA. International Journal of Energy and Environment, $\quad 10, \quad 52-60 . \quad$ Retrieved from https://www.naun.org/main/NAUN/energyenvironment/2016/a142011-065.pdf

Binford, S., \& Binford, L. (Eds.). (1968). New Perspectives in Archeology. Chicago, Illinois: Aldine Publishing Company.

Boults, E, \& Sullivan, C. (2010). Illustrated History of Landscape Design. Hoboken, New Jersey: John Wiley \& Sons, Inc. 


\section{Mll Macrothink}

Bullen, R. (2016). Chinese sources in the Japanese tea garden. Studies in the History of Gardens \& Designed Landscapes, 36(1), 5-16. https://doi.org/10.1080/14601176.2015.1076667

Burley, J. B. (1992). Gheo-Shih: an ancient Pre-Columbian plaza. Landscape Research, 17(2), 74-78. https://doi.org/10.1080/01426399208706365

Burley, J. B., \& Kopinski, E. (2014). Villa Lante: Italy's greatest renaissance garden. The Michigan Landscape, 57(2: March/April), 27-30.

Burley, J. B., \& Loures, L. (2010). Conceptual precedent: seven historic sites revisited. WSEAS Transactions on Environment and Development, 6(12), 783-792. Retrieved from http://www.wseas.us/e-library/transactions/environment/2010/52-099.pdf

Burley, J. B., \& Machemer, T. (2016) From Eye to Heart: Exterior Spaces Explored and Explained (1st ed). San Diego, California: Cognella Academic Publishing.

Burley, J. B., \& Yilmaz, R. (2014). Visual quality preference: the Smyser index variables. International Journal of Energy and Environment, 8, 147-153. Retrieved from https://www.naun.org/main/NAUN/energyenvironment/2014/a222011-140.pdf

Burley, J. B., Fowler. G. W., Polakowski, K., \& Brown, T. J. (2001). Soil based vegetation productivity model for the North Dakota coal mining region. International Journal of Surface Mining, Reclamation, and Environment, 15(4), 213-234. https://doi.org/10.1076/ijsm.15.4.213.7415

Burley, J. B., Thomsen, C., \& Kenkel, N. (1989). Development of an agricultural productivity model to reclaim surface mines in Clay County, Minnesota. Environmental Management, 13(5), 631-638. https://doi.org/10.1007/BF01874969

Burley, J. B., Wu, Z., He, S., \& Li, X. (2020). Soil-based vegetation productivity models for disturbed lands along the northern and Central western Great Plains, USA. Journal of Advanced Agricultural Technologies, 7(1), 1-7. https://doi.org/10.18178/joaat.7.1.1-7

Cali, J., \& Dougill, J. (2012). Shinto Shrines: A guide to the Sacred Sites of Japan's Ancient Religion. Honolulu, Hawaii: Latitude 20. https://doi.org/10.1515/9780824837754

Casault, J., \& Burley, J. B. (2010). Restored Versailles: A French Garden with a message. The Michigan Landscape, November/December, 37-42.

Chambers, W. (1772). A Dissertation on Oriental Gardening. London, United Kingdom: W. Griffin, Royal Academy. https://doi.org/10.5962/bhl.title.63968

Chen, D., \& Burley, J.B. (2018). Japanese authenticity: gardens of simplicity and meaning. The Michigan Landscape, 18, 52-56.

Chen, G. (2008). What is the difference between Japanese and Chinese gardens? Washington Park Arboretum Bulletin, 3, 25-29. Retrieved from https://www.biodiversitylibrary.org/item/237270\#page/1/mode/1up 
Chen, W. (1991). A comparative study on Chinese private garden and Japanese dry landscape garden from aesthetics point of view. The Architect, 41, 115-124. https://doi.org/10.3130/jaabe.2.b69

Cheng, J. (translated by A. Hardie 2012). (1631). The Craft of Gardens: the Classic Chinese Text on Garden Design. Shanghai, P. R. of China: Shanghai Press.

Chongzhou, C. (2008). On Chinese Gardens. Shanghai, P. R. of China: Tongji University Press. Clancy, J. (2015). Kyoto Gardens: Masterworks of the Japanese Gardener's Art. Clarendon, Vermont: Tuttle Publishing.

Coe, M. (1987). The Maya. Thames Hudson: New York, New York, fourth edition.

Courtney, W.W., \& Elardo, R. J., (Eds.). (2012). People and Plants: the Harper Collection of Rare and Dwarf Conifers. Tipton, Michigan: Hidden Lakes Garden, Michigan State University.

Curtis, J. T. (1959). The Vegetation of Wisconsin: A Plant Community Ordination. University of Wisconsin Press.

Darkovskaya, A. S., Li, X., \& Burley, J. B. (2010). Historical continuity: landscape monuments and sacred places: connecting the past with the present. Harmony and Prosperity, Traditional Inheritance and Sustainable Development, 47 th IFLA Congress and CHSLA Annual Meeting, Suzhou China. Suzhou, P. R. of China: International Federation of Landscape Architects.

Desranleau, J., \& Jacobs, P. (2009). From conception to reception: Transforming the Japanese garden in the Montreal botanical garden. Studies in the History of Gardens \& Designed Landscapes, 29(3), 200-216. https://doi.org/10.1080/14601170701788916

Dougill, J. (2017). Zen Gardens and Temples of Kyoto: a Guide to Kyoto's Most Important Sites. Clarendon, Vermont: Tuttle Publishing.

Feng, M., Burley, J. B., Machemer, T., Korkmaz, A., \& Villanueva, M. R. (2018). Earthquake spatial mitigation: Wenchuan China and Los Banos, Philippines Case Studies. GSTF Journal of Engineering Technology (JET), 5(2), 10.

Fowler, M. (2015). Sound as a considered design parameter in the Japanese garden. Studies in the History of Gardens \& Designed Landscapes, 35(4), 312-327. https://doi.org/10.1080/14601176.2015.1049478

Fuji, E., Baik, J., Kim, J., \& Jang, M. (2017). Characteristics of Japanese garden: comparisons in Korea, China and the West. ISHS Acta Horticulturae, 759.

Gothien, M. L. (Wrigth, A.P., \& M.A. Archer-Hind translator of German). (1928). A History of Garden Art. New York, New York: E.P. Dutton \& Company LtD.

Goto, S., Ristovska, L., \& Fujii, E. (2014). The Japanese garden at Sonnenberg: The first traditional private Japanese garden in North America. Studies in the History of Gardens \& Designed Landscapes, 34(4), 295-308. https://doi.org/10.1080/14601176.2013.849053

Jellicoe, G., \& Jellicoe, S. (1975). The Landscape of Man: Shaping the Environment from 
Prehistory to the Present Day. Viking Press, New York.

Jie, H. (2013). The Splendid Chinese Garden: Origins, Aesthetics and Architecture. Shanghai, P. R. of China: Shanghai Press.

Kawaguchi, Y. (2016). Authentic Japanese Gardens: Creating Japanese Design and Detail in the Western Garden. Location undisclosed: Design Originals (IMM Lifestyle Books).

Keswick, M. (1978). The Chinese Garden: History, Art \& Architecture. London, United Kingdom: Academy Editions.

Kopinski, E., \& Burley, J. B. (2013). Giverny: Claude Monnet's Garden Retreat. The Michigan Landscape, September/October:35, 38-41.

Kuck, L. (1968). The World of the Garden: from Chinese Origins to Modern Landscape Art. New York, New York: Walker/Weatherhill.

Kuitert, W. (2002). Themes in the History of Japanese Garden Art Honolulu, Hawaii: University of Hawaii Press.

Li, N., Wang, L., X., Jin, X. Yue, Z., Machemer, T., Zhou, J., \& Burley, J. B. (2020). An ordination of selected artists, painters, and designers: line, composition, color. Journal of Architecture and Construction, 3(1), 37-51. Retrieved from http://www.sryahwapublications.com/journal-of-architecture-and-construction/pdf/v3i1/4.pdf

Lin, W., Burley, J. B., Nieratko, P., \& Machemer, T. (2017). Railroad station arrival cognition: way-finding at the East Lansing train station. $3^{\text {rd }}$ Annual International Conference on Urban Planning and Property Development (UPPD 2017). Global Science \& Technology Forum (GSFT), 91-97.

Liu, C., Burley, J. B., \& Partin, S. (2014). A metaphor for design: fishing and seclusion-the master-of-nets garden, Suzhou, China. The Michigan Landscape, 57(6: November/December), $32-33,36-42$.

Loures, L., \& Burley, J. B. (2009). Conceptual Precedent: Seven Historic Sites Revisited. WSEAS Transactions on Environment and Development, 5(1), 55-64.

Lu, A. (2011). Lost in translation: Modernist interpretation of the Chinese Garden as experiential space and its assumptions. The Journal of Architecture, 16(4), 499-527, https://doi.org/10.1080/13602365.2011.598703

Lung-Ming, T. (2016). A study on the beauty of Zen garden - cases of Ginkaku Temple, Ryoan Temple, and Sankei Garden. American Journal of Sociological Research, 6(4), 91-98.

Makowska, B. (2014). Integrating architecture and the created landscape in Japanese gardens. International Journal of Arts \& Sciences, 7(5), 597-604. Retrieved from http://www.universitypublications.net/ijas/0705/html/P4RS298.xml

Mangin, A., (1887). Histoire des Jardins Anciens et Modernes. Tours, France: Alfred Mame et 
fils (and son).

Mehta, G. K., Tada, K., \& Murata, N. (2008). Japanese Gardens: Tranquility, Simplicity, Harmony. Tokyo: Tuttle Pub.

Newton, N. T. (1974). Design on the Land: The Development of Landscape Architecture. Cambridge, Massachusetts: The Belknap Press.

Ogata, T., Li, W., \& Yamada, S. (2010). A mapping and geographical analysis of Japanese gardens in the Kyoto basin. Japan Review, 22(22), 213-221. http://doi.org/10.15055/00000210

Peng, Z. (2016). The comparative study of Chinese-Japanese temple garden stones. 2nd International Conference on Education Technology, Management and Humanities Science (ETMHS 2016). Atlantis Press, Paris, France/Beijing, P.R. of China: ETMHS, 297-300.

Peregoy, B. (2015). Peek inside the new Japanese garden at Meijer Gardens. Architectural Digest, May. Retrieved from https://www.architecturaldigest.com/story/new-japanese-gardenmeijer-garden-and-sculpture-park

Powell, K. (2002). Neuroscience unlocks secrets of Zen garden. Nature, September. https://doi.org/10.1038/news020926-8

Pregill, P., \& Volkman, N. (1999). Landscapes in History: Design and Planning in the Eastern and Western Tradition (2nd ed). Hoboken, New Jersey: John Wiley \& Sons, Inc.

Qi, J., Wang, S., Burley, J. B., \& Machemer, T. (translated by Sihui Wang). (2012). Defining ecological regions in Michigan based on native tree distributions. Landscape Architecture, (6), 138-145.

Qingxi, L. (translated by Z. Lei, Y Hong). (2003). Chinese Gardens. Beijing, P. R. of China International Press.

SAS. (2012). Version: 9.4 TS Level 1M2, X64_8PRO platform, English. Cary, North Carolina: SAS Institute Inc.,

Shukyoku, J. M. (1920). Handbook of the old shrines and temples and their treasures in Japan. Tokyo: Bureau of Religions, Department of Education.

Siciliano, P. C. (2005). Landscape Interpretations: History, Techniques and Design Inspirations. Clifton Park, New York: Delmar Learning.

Sun, L., Wang, Y., \& Leng, J. (2019). A study of museum courtyard space in eastern China. Journal of Asian Architecture and Building Engineering, 18(1), 28-42. https://doi.org/10.1080/13467581.2019.1601566

Suzuki, A. (2015). Opportunities, obstacles and possibilities for foreigners to study traditional Japanese gardening. Intercultural Understanding, 5, 21-27. Retrieved from https://www.mukogawa-u.ac.jp/ itcs/publications/IU_vol5/pdf/IU_vol.5_1-3_article.pdf

Takei, J., \& Keane, P. M. (2008). Sakuteiki: Visions of the Japanese Garden: A Modern Translation of Japan's Gardening Classic. Clarendon, Vermont: Tuttle Publishing. 
Tobey, G. B. Jr. (1973). A History of Landscape Architecture: The Relationship of People to Environment. New York: American Elsevier Publishing Company, Inc.

Tokyo Metropolitan Park Association. (undated). Kiyosumi Gardens. Tokyo: Tokyo Metropolitan Park Association,.

Treib, M., \& Herman, R. (2003). A guide to the gardens of Kyoto. Tokyo: Kodansha.

Valders, P. (2002). Gardens in China. Portland, Oregon: Timber Press.

Van Tonder, G. J., Lyons, M. J., \& Ejima, Y. (2002). Visual structure of a Japanese Zen garden. Nature, 419(6905), 359. https://doi.org/10.1038/419359a

Wang, H., Chen, S., \& Burley, J. B. (2010). The prohibitive regulation tablet, Xiaoling Tomb of the Ming Dynasty. Harmony and Prosperity, Traditional Inheritance and Sustainable Development, $47^{\text {th }}$ IFLA Congress and CHSLA Annual Meeting, Suzhou China. Suzhou, P. R. of China: International Federation of Landscape Architects.

Wang, H., Leng, J., \& Ouyang, Q. (2014). Characteristics and transformation of private gardens of Nanjing in modern Chinese history. International Journal of Energy and Environment, 8, 118-126. Retrieved from https://www.naun.org/main/NAUN/energyenvironment/2014/a162004-109.pdf

Wang, M., Hyde. R. Q., Burley, J. B., Allen, A., \& Machemer, T. (2015). Low-impact housing: River Rouge, Michigan. Housing and Society, 42(3), 193-206. https://doi.org/10.1080/08882746.2015.1121679

Wang, Y., \& Burley, J. B. (2009). Collector's (trophy trees) desired plants for across the globe: a Michigan and Chinese perspective. The Michigan Landscape, 52(10), 26-33.

Wen, B., \& Burley, J. B. (2020). Expert Opinion Dimensions of Rural Landscape Quality in Xiangxi, Hunan, P.R. of China: Principal Component Analysis and Factor Analysis. Sustainability, 12(4), 1316. https://doi.org/10.3390/su12041316

Whysall, S. (2015). Into the great gardens of China. Vancouver Sun, 7 May. Retrieved from https://vancouversun.com/news/staff-blogs/into-the-great-gardens-of-china

Wilson, M. (2019). How Asian gardens have taken root in America. Financial Times, 19 January. Retrieved from https://www.ft.com/content/6a00b4b4-140a-11e9-a168d45595ad076d

Wuzhong, Z. (2005). A comparative study on Chinese and Western classical garden arts. Canadian Social Science, 3, 83-90. http://dx.doi.org/10.3968/j.css.1923669720050103.012

Xu, H., Burley, J. B., Crawford, P., Wang, Y., Yue, Z., \& Schutzki, R. (2017). An ordination of western and Chinese burial sites. WSEAS Transactions on Environment and Development, 13, 452-469.

Retrieved

from

https://www.wseas.org/multimedia/journals/environment/2017/a925915-008.php

Xu, Y. (2015). A Cluster Analysis Comparison of Classical Chinese Gardens with Modern 
Chinese Gardens. Master of Environmental Design Thesis, East, Lansing, Michigan.

Xu, Y., Burley, J. B., Machemer, P., \& Allen, A. (2016). A dimensional comparison between classical Chinese gardens and modern Chinese gardens. WSEAS Transactions on Environment and Development, 12, 200-213. Retrieved from https://www.wseas.org/multimedia/journals/environment/2016/a425815-320.pdf

Yang, B., \& Volkman, N.J. (2010). From traditional to contemporary: Revelations in Chinese garden and public space design. Urban Design International, 15, 208-220. https://doi.org/10.1057/udi.2010.13

Young, D., \& Young, H. (2005). The Art of the Japanese Garden: History | Culture | Design. Clarendon, Vermont: Tuttle Publishing.

Yue, Z., Wei, S., \& Burley, J. B. (2012). Non-Euclidian methods to replicate urban and garden patterns in P.R. of China. International Journal of Energy, 6(3), 105-114. Retrieved from https://naun.org/main/NAUN/energy/17-769.pdf

Zhang, D. (2017). Classical Chinese gardens: Landscape for self-cultivation. Journal of Contemporary Urban Affairs, 2(1), 33-44. https://doi.org/10.25034/ijcua.2018.3654

Zhao, C., Matsumoto, N., Liu, T., Yuan, Y., \& Katsuhiro K. (2003). A study on the image of landscape of Japanese and Chinese gardens. Journal of Asian Architecture and Building Engineering, 2(2), b69-b76. https://doi.org/10.3130/jaabe.2.b69

\section{Appendix 1}

Table A1: Principal Component coefficient of variables for the first three principal components.

\begin{tabular}{cccc}
\hline Covered walkways (lang) & 0.115325 & 0.032365 & -0.029995 \\
Pavillions (ting xie) & 0.115325 & 0.032365 & -0.029995 \\
Viewing terrace & 0.063079 & -0.133227 & 0.11619 \\
Black tile pavement & -0.013109 & 0.160909 & -0.101168 \\
Brick paving & 0.031125 & 0.161275 & -0.025306 \\
\hline & & & \\
\hline Design Elements and Principles & Prin1 & Prin2 & Prin3 \\
\hline Cracked ice stone paving & 0.04896 & 0.082795 & 0.06076 \\
Pebbles area & 0.037908 & -0.148157 & 0.048379 \\
Mosaic pave with special pattern & -0.030621 & 0.152181 & 0.135471 \\
Whitewashed walls & 0.079295 & 0.03028 & 0.114183 \\
Grey stone walls & -0.000197 & -0.021784 & -0.051829 \\
Openwork brick walls & -0.078724 & 0.13065 & 0.081931 \\
Curved top walls & 0.016686 & 0.154538 & -0.014102 \\
Zigzag wall & -0.009346 & 0.166475 & 0.034001 \\
Meandering walls & 0.016686 & 0.154538 & -0.014102 \\
Bamboo paved pathway & -0.058808 & -0.014097 & -0.191336
\end{tabular}




\begin{tabular}{|c|c|c|c|}
\hline Boardwalk & -0.058808 & -0.014097 & -0.191336 \\
\hline Curved Pathway & 0.051514 & 0.026468 & -0.169117 \\
\hline Straight Pathway & 0.083454 & 0.02159 & 0.244795 \\
\hline Zigzag Bridge & -0.009346 & 0.166475 & 0.034001 \\
\hline Semi-circular bridge & 0.06263 & 0.057576 & -0.00583 \\
\hline Straight Bridge & 0.036083 & 0.072854 & 0.11728 \\
\hline Wall holes with symbolized shape & -0.009346 & 0.166475 & 0.034001 \\
\hline Lattice window & 0.130476 & 0.023033 & -0.03526 \\
\hline Moon Gate & 0.019605 & 0.189043 & -0.024031 \\
\hline Wood carvings & 0.115325 & 0.032365 & -0.029995 \\
\hline Glass carvings & -0.066891 & -0.007286 & 0.221572 \\
\hline Brick carvings & 0.031835 & 0.162186 & -0.014781 \\
\hline Reflecting Pond & 0.03706 & 0.034377 & 0.160483 \\
\hline Stream & 0.119064 & -0.029195 & -0.025043 \\
\hline Fish pond & 0.09633 & 0.032734 & -0.11836 \\
\hline Wetland & -0.078476 & -0.014226 & -0.065983 \\
\hline Island & 0.080989 & 0.005885 & 0.042502 \\
\hline Artificial mountains & 0.019605 & 0.189043 & -0.024031 \\
\hline Sculptural rocks & 0.05569 & 0.015524 & 0.144519 \\
\hline Pond bank rocks & 0.108178 & 0.053326 & -0.014145 \\
\hline Taihu rocks /scholars' stone & 0.019605 & 0.189043 & -0.024031 \\
\hline Trees & 0.083454 & 0.02159 & 0.244795 \\
\hline Shrubs & 0.100406 & 0.021538 & 0.144469 \\
\hline Ground covers & 0.079486 & 0.032404 & -0.02688 \\
\hline Turf area & -0.031626 & 0.046562 & 0.136078 \\
\hline Pine & 0.11602 & 0.021383 & 0.054663 \\
\hline Bamboo & 0.083454 & 0.02159 & 0.244795 \\
\hline Plum & 0.130476 & 0.023033 & -0.03526 \\
\hline Magnolias & 0.130476 & 0.023033 & -0.03526 \\
\hline Camellia & 0.120103 & 0.037952 & -0.019487 \\
\hline Crepe myrtles & 0.130476 & 0.023033 & -0.03526 \\
\hline Sweet osmanthus & 0.11602 & 0.021383 & 0.054663 \\
\hline Peony & 0.043471 & 0.12873 & -0.003882 \\
\hline Willow & 0.019605 & 0.189043 & -0.024031 \\
\hline Lotus & 0.021541 & 0.089944 & 0.131182 \\
\hline Reed & 0.007588 & -0.073862 & -0.03434 \\
\hline Sugar cane & -0.05569 & -0.015524 & -0.144519 \\
\hline Moon & 0.055001 & 0.026302 & -0.043892 \\
\hline Clouds & 0.065671 & 0.012178 & -0.042809 \\
\hline Rain & 0.075677 & 0.02657 & -0.015644 \\
\hline Wind & 0.039999 & 0.131885 & -0.029707 \\
\hline Shadow & 0.067843 & -0.089983 & -0.028109 \\
\hline Originally private & 0.108178 & 0.053326 & -0.014145 \\
\hline
\end{tabular}




\author{
Located in suburban \\ Located in urban \\ Design concept \\ Poem and painting concept \\ Naturainess \\ Varied spaces with visual devices \\ Borrowed scenery \\ Enframed scenery \\ Opposite scenery \\ Contrast \\ Deep implication \\ Abstract geometrical composition \\ Miniature of natural landscapes \\ Boating pond \\ Stepping stones \\ Yellow painted wall \\ Unpainted structures or elements \\ Fall colour of plant material \\ Metal components in wooden structures \\ Courtyard/atrium \\ Wooden /bamboo fence/railings \\ Bench \\ Pagoda \\ Adjacent to burial site \\ Stairs \\ Geomancy rules/Fengshui \\ Stone lanterns \\ Wooden lanterns \\ Trellis/pergola \\ Obviouly exposed drainage ditch/gutter \\ Signage stone \\ Elevation change \\ Plaque \\ Lifted base of building \\ Building partially painted in red \\ Strings implied enchantment boundary \\ Raked sand design \\ Stone hand wash basin \\ Well \\ Bell \\ Shishiodoshi \\ Grouping stones
}

Public

\begin{tabular}{|c|c|c|}
\hline-0.108178 & -0.053326 & 0.014145 \\
\hline-0.032962 & -0.132783 & 0.03824 \\
\hline 0.032962 & 0.132783 & -0.03824 \\
\hline 0 & 0 & 0 \\
\hline 0.070807 & 0.052928 & 0.14007 \\
\hline 0.06809 & 0.00849 & -0.196042 \\
\hline 0.058808 & 0.014097 & 0.191336 \\
\hline 0.108169 & 0.017047 & -0.143409 \\
\hline 0.014341 & 0.049622 & 0.103526 \\
\hline 0.083454 & 0.02159 & 0.244795 \\
\hline 0 & 0 & 0 \\
\hline 0 & 0 & 0 \\
\hline-0.019605 & -0.189043 & 0.024031 \\
\hline 0.108178 & 0.053326 & -0.014145 \\
\hline 0.057645 & 0.050134 & -0.011622 \\
\hline 0.081895 & -0.077878 & 0.010753 \\
\hline 0.072115 & -0.07412 & 0.005157 \\
\hline 0.130476 & 0.023033 & -0.03526 \\
\hline 0.130476 & 0.023033 & -0.03526 \\
\hline 0.102906 & -0.121021 & -0.01376 \\
\hline 0.104842 & 0.050013 & -0.012316 \\
\hline 0.052559 & -0.094241 & 0.205522 \\
\hline-0.021705 & -0.065217 & 0.202628 \\
\hline 0.091426 & -0.089466 & 0.004146 \\
\hline 0.094117 & -0.110391 & -0.010368 \\
\hline 0.03655 & -0.146899 & 0.031848 \\
\hline 0.109887 & 0.016261 & -0.117615 \\
\hline 0.102906 & -0.121021 & -0.01376 \\
\hline 0.063244 & -0.081409 & -0.026879 \\
\hline 0.073442 & 0.082069 & -0.001974 \\
\hline 0.102906 & -0.121021 & -0.01376 \\
\hline 0.102906 & -0.121021 & -0.01376 \\
\hline 0.130476 & 0.023033 & -0.03526 \\
\hline 0.130476 & 0.023033 & -0.03526 \\
\hline 0.130476 & 0.023033 & -0.03526 \\
\hline 0.073225 & 0.070826 & -0.044972 \\
\hline 0.01815 & -0.049893 & -0.028311 \\
\hline 0.072115 & -0.07412 & 0.005157 \\
\hline 0.102906 & -0.121021 & -0.01376 \\
\hline 0.130476 & 0.023033 & -0.03526 \\
\hline 0.094117 & -0.110391 & -0.010368 \\
\hline 0.017794 & -0.021568 & -0.007219 \\
\hline 0.108178 & 0.053326 & -0.014145 \\
\hline
\end{tabular}




\begin{tabular}{|c|c|c|c|}
\hline Ophiopogon japonicus & 0.031835 & 0.162186 & -0.014781 \\
\hline Hydrangea & 0.102906 & -0.121021 & -0.01376 \\
\hline Japanese Maple & 0.130476 & 0.023033 & -0.03526 \\
\hline Moss & 0.098621 & -0.105123 & -0.000461 \\
\hline Azalea & 0.100406 & 0.021538 & 0.144469 \\
\hline Trimmed plant material & 0.083454 & 0.02159 & 0.244795 \\
\hline Weeping form plant material & 0.107777 & 0.046833 & -0.015451 \\
\hline Multiple layers of entry sequence & 0.130476 & 0.023033 & -0.03526 \\
\hline Multiple layers of edges & 0.130476 & 0.023033 & -0.03526 \\
\hline Control view point & 0.097762 & 0.022034 & 0.103072 \\
\hline Foreground, Midground, and Background & 0.130476 & 0.023033 & -0.03526 \\
\hline Large scale & 0.081233 & -0.090702 & 0.006129 \\
\hline Small scale & -0.081233 & 0.090702 & -0.006129 \\
\hline Located on the foot of mountain & 0.091001 & -0.113464 & -0.010545 \\
\hline Location adjacent to Shinto Shrine & 0.102906 & -0.121021 & -0.01376 \\
\hline Curved roof & 0.115325 & 0.032365 & -0.029995 \\
\hline Chinese characters & 0.130476 & 0.023033 & -0.03526 \\
\hline Wabi-sabi & 0.102906 & -0.121021 & -0.01376 \\
\hline Religious property & 0.102906 & -0.121021 & -0.01376 \\
\hline Teaism & 0.095049 & 0.065378 & -0.007474 \\
\hline Sense of sacred place & 0.130476 & 0.023033 & -0.03526 \\
\hline Animistic believes & 0.130476 & 0.023033 & -0.03526 \\
\hline Buddhism & 0.10198 & 0.008273 & -0.004773 \\
\hline Shinto & 0.053985 & -0.078082 & -0.024796 \\
\hline Confucianism & 0.027379 & 0.157579 & -0.025519 \\
\hline Imperial background & 0.102906 & -0.121021 & -0.01376 \\
\hline Simplicity & 0 & 0 & 0 \\
\hline Tranquility & 0.130476 & 0.023033 & -0.03526 \\
\hline Harmony & 0.130476 & 0.023033 & -0.03526 \\
\hline
\end{tabular}

\section{Copyrights}

Copyright for this article is retained by the author(s), with first publication rights granted to the journal.

This is an open-access article distributed under the terms and conditions of the Creative Commons Attribution license (http://creativecommons.org/licenses/by/4.0/) 